\title{
COMPORTAMENTO E VARIABILIDADE DE GENÓTIPOS \\ DE SOJA (glycine max (L.) MERRILL) \\ EM CULTIVOS DE VERÃO E INVERNO
}

\author{
JOÃO TOME DE FARIAS NETO \\ Engenheiro Agrônomo
}

Orientador: Prof. Dr. NATAL ANTONIO VELLO

Dissertação apresentada à Escola Superior de Agricultura "Luiz de Queiroz", da Universidade de São Paulo, para obtenção do título de Mestre em Agronomia. Área de Concentração: Genética e Melhora mento de Plantas.

PIRACICABA

Estado de são Paulo - Brasil

Out.ubro de 1987 
Farias Neto, João Tomé de

F224c Comportamento e variabilidade de genótipos

de soja (Glycine max (L.) Merrill) em cultivos

de verão e inverno. Piracicaba, 1987.

$87 p$.

Diss.(Mestre) - ESALQ

Bibliografia.

1. Soja - Cultivo. 2. Soja - Genótipo. 3. So

ja - Melhoramento. I. Escola Superior de Agricul tura Luiz de Queiroz, Piracicaba

CDD 633.34 


\section{Aos meus pais \\ JOAO TOME DE FARIAS FILHO $e$ \\ ZI LMA CARVALHO DA CONCEIÇAO FARIAS \\ OFEREÇO.}




\section{AGRADECIMENTOS}

Desejamos expressar nossos agradecimentos aque les que, direta e indiretamente, contribuíram para a realização deste trabalho em em especial, às seguintes pessoas e instituições:

- ao Prof. Dr. Natal Antonio Vello, pela valio sa orientação, ensinamentos, amizade e constante incentivo;

- à Empresa Brasileira de Pesquisa Agropecuária - EMBRAPA e ao Conselho Nacional de Desenvolvimento Científico e Tecnológico - CNPq, pelas bolsas de estudo ofereci das e que tornaram possível a realização deste trabalho;

e cooperação;

- ao colega Luciano Lourenço Nass, pelo apoio

- a bibliotecária Nilce T.P. Sigrist pela revi são da literatura citada;

- aos docentes do Departamento e Instituto de Genética, pelos ensinamentos recebidos;

- aos funcionários do Departamento e Institu to de Genëtica, especialmente do Setor de Genêtica Aplicada às Espēcies Autögamas, pelos auxilios prestados;

- aos colegas do curso de pós-graduação, pela amizade, estímulo e companheirismo. 


\section{INDICE}

pägina

RESUMO $\ldots \ldots \ldots \ldots \ldots \ldots \ldots \ldots \ldots \ldots \ldots \ldots \ldots \ldots \ldots \ldots \ldots$

SUMMARY $\ldots \ldots \ldots \ldots \ldots \ldots \ldots \ldots \ldots \ldots \ldots \ldots \ldots \ldots \ldots \ldots \ldots \ldots \ldots$

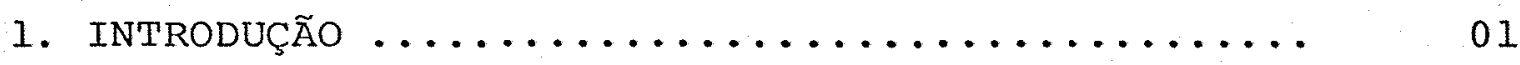

2. REVISÃo DE IITERATURA .................... 04

2.1. Classificação das espécies quanto ao fotoperíodo ......................... 04

2.2. Fotoperíodo e indução floral ........... 05

2.3. Temperatura ..................... 09

2.4. Epocas de plantio ................. II

2.5. Identificação de genótipos menos sensiveisao fotoperiodo ................... 14

2.6. Estimação de parãmetros genéticos e fenoti-

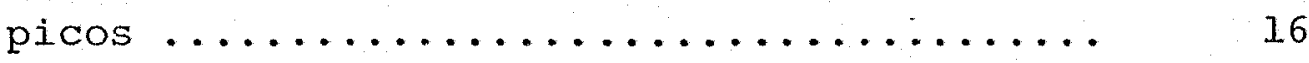

3. MATERIAIS E METOdOS ..................... 20

3.1. Tratamento estatístico-genético ......... 24

3.1.1. Análises individuais e conjuntas da variância .................... 24

3.1.2. Estimativas de parâmetros genéticos e

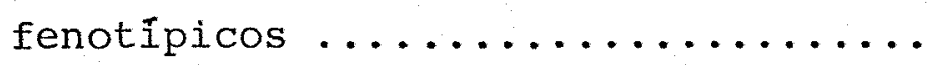

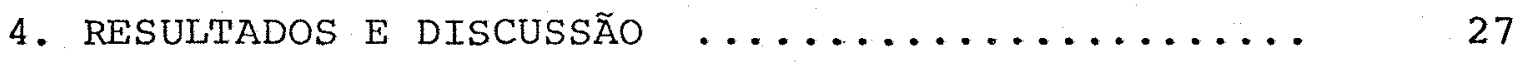

4.1. Duração dos estádios da planta ........... 29

4.2. Altura e nümero de internódios da planta no

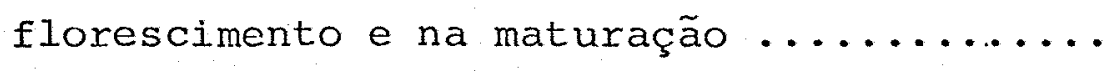

4.3. Acamamento ..................... 37

4.4. Altura de inserção da primeira vagem ..... 37

4.5. Prođução de grãos ................. 38 
4.6. Estimativas dos parâmetros genéticos e feno

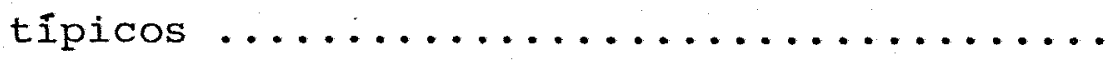

5. CONCLUSÕES $\ldots \ldots \ldots \ldots \ldots \ldots \ldots \ldots \ldots \ldots \ldots \ldots \ldots \ldots \ldots \ldots \ldots$

6. REFERENCIAS BIBLIOGRAFICAS ..............

TABELAS $\ldots \ldots \ldots \ldots \ldots \ldots \ldots \ldots \ldots \ldots \ldots \ldots \ldots \ldots \ldots \ldots \ldots \ldots$

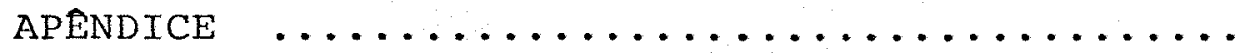


vi.

COMPORTAMENTO E VARIABILIDADE DE GENOTIPOS DE SOJA (Glycine max (L.) Merril1) EM CULTIVOS DE VERÃO E INVERNO

\author{
Autor: JOÃO TOME DE FARIAS NETO \\ Orientador: Prof. Dr. NATAL ANTONIO VELLO
}

RESUMO

Na época normal de cultivo no Estado de são Paulo, a soja tem sido semeada principalmente entre 15 de outubro e 15 de novembro. Entretanto, em um dos sistemas de sucessão de culturas, asoja também vem sendo cultivada no inverno, com plantios nos meses de janeiro a março; condições ambientais representadas por fotoperiodos mais curtos e temperaturas mais baixas prevalecentes durante os cultivos de in verno seriam desfavorāveis para o desenvolvimento vegetativo e reprodutivo da soja.

Com o objetivo de verificar as alterações ocor ridas nas plantas cultivadas no inverno, relativamente ao cul tivo de verão, foram conduzidos dois experimentos em Piracica ba, Estado de são Paulo, em ambiente caracterizado por 22942' de latitude sul, 47938' de longitude oeste, 537 metros de altitude e solo do tipo terra roxa estruturada. Cada experimen to foi delineado em blocos ao acaso com quatro repetições e 30 tratamentos estratificados em dois conjuntos experimentais den tro de cada repetição. Cada conjunto experimental compreendeu 15 genótipos e três testemunhas comuns. As semeaduras fo 
ram realizadas em $07 / 11 / 85$ e 12/03/86 para os cultivos de verão e inverno, respectivamente. Foram avaliados dez caracteres: tempo para florescimento, tempo para maturação, período reprodutivo, altura da planta no florescimento e na maturação, número de internódios no florescimento e na maturação, a camamento, altura de inserção da primeira vagem e produtivida de. Foram estimados os seguintes parâmetros: médias, interações genótipos $\mathrm{x}$ épocas de cultivo, coeficientes de determinação genotípica, correlações fenotípicas entre caracteres e correlações entre épocas de cul tivo.

Tanto o efeito dos genótipos quanto a interação entre genótipos e épocas de cultivo foram significativos para os caracteres. As médias de todos os caracteres foram inferiores no cultivo de inverno. O encurtamento do tempo pa ra maturação foi consequência mais da redução no tempo para florescimento do que do período reprodutivo. A seleção para produtividade mostrou-se dependente da época de cultivo, mas - genótipo BR-9 comportou-se favoravelmente nas duas épocas. Caracteres como tempo para florescimento e altura da planta no florescimento podem auxiliar a seleção para produtividade no inverno. A incorporação de genes para período juvenil lon go nos cultivares mostrou-se ser uma estratégia promissora pa ra neutralizar o efeito das épocas de cultivo e/ou baixas latitudes sobre o comportamento dos genótipos de soja. 
viii.

PERFORMANCE AND VARIABILITY OF SOYBEAN (Glycine max (L.) Merril1) GENOTYPES AS SUMMER AND WINTER CROPS

Author: JOÃO TOME DE FARIAS NETO

Adviser: Prof. Dr. NATAL ANTONIO VELLO

SUMMARY

For the normal season of cultivation (summer crop) in state of são paulo (Brazil) soybeans has been mainly sown between October $15^{\text {th }}$ and November $15^{\text {th }}$. However, in sequential cropping patterns, soybeans has been cultivated as a winter crop with scwing made between January and March. Relatively to the normal season, shorter photoperiods and lower temperatures prevailing in the winter crop would be unfavorable for vegetative and reproductive development of soybean plants.

In order to verify the plant response as sumer and winter crops, two experiments were carried out in Piraciba, State of São Paulo, Brazil, at 22942' South latitude, 47 9 $38^{\circ}$ West longitude, and $537 \mathrm{~m}$ altitude. Each experiment corresponded to a complete randomized block design with four replications and 30 genotypes stratified in two sets. Each set included 15 genotypes and three checks. The sowings were made in November 11, 1985 and March 12, 1986, respectively for summer and winter crops. It was evaluated ten characters: flowering time, maturity time, reproductive period, plant 
height at flowering and maturity, number of internodes at flowering and maturity, lodging, first pod height insertion, and seed yield. Estimates were obtained to the following parameters: means, genotype $x$ crop season interactions, coef ficients of genotypic determination, phenotypic correlations between characters, and correlations between crop seasons.

Genotypes and genotype $\mathrm{x}$ crop season interactions were significative for all characters. Inferior mean values were observed for all characters in winter crop. The reduction in maturity time was consequence primarily from a shorter flowering time and, secondly, from a shorter reproductive period. Selection for seed yield was dependent of crop season, but the BR 9 genotype performed favorably in both crop seasons. Flowering time and plant heigth at flowering could be useful characters in selecting indirectly for seed yield. The incorporation of genes for long juvenile period would be a promissing strategy to neutralize the season and/ or low latitude effect on the performance of soybean genotypes. 


\section{INTRODUCẼ̃O}

A soja (Glycine max (L.) Merrill) é uma espécie autógama, amplamente cultivada em todos os continentes. o interesse mundial pela soja deve-se à combinação ótima que a espēcie apresenta em termos de: produção de grãos, em torno de $2 t / h a$, porcentagem de proteina, representando em média $40 \%$ do peso das sementes; porcentagem de óleo correspondente a 20\% do peso das sementes (VELLO, 1985).

No Brasil, o cultivo da soja teve grande expansão nos anos setenta, quando a produção nacional anual passou de 1,5 para 15 milhões de toneladas. A área de cultivo com soja representa $20 \%$ do total de ăreas cultivadas, correspondendo aproximadamente à 8,7 milhões de hectares.

Trata-se de uma espécie de dias curtos, tendo sido inclusive o material utilizado para o desenvolvimento des ta teoria, que diz que cada cultivar necessita de um certo nū mero de horas de escuro contínuo para que sofra indução ao florescimento. Como o florescimento condiciona a altura da planta, a resposta dos cultivares ao comprimento do dia e da noite (fotoperíodo) é o fator mais importante para a adaptação de um cultivar.

Uma contribuição recente da pesquisa agronômi- 
ca, importante para o desenvolvimento de cultivares de soja, foi o desenvolvimento de cultivares com período juvenil mais longo.

Denomina-se de período juvenil ao espaço de tempo compreendido entre a data da emergência da plântula até - dia em que ela começa a receber estímulos para florescer. Portanto, o período juvenil é o número de dias em que a plântula permanece insensível à produção de substâncias florígenas, apesar do fotoperiodo ser apropriado para induzir a sintese destas substâncias. Considerando que a planta necessita de vários dias para produzir florígenos em quantidade suficiente para estimular o inicio do florescimento, então, o período juvenil representa apenas uma parte do periodo vegetatí vo. Cultivares com período juvenil longo desenvolvem-se vege tativamente bem e alcançam altura de planta apropriada para produção de sementes em níveis econômicos, mesmo sob condições variáveis de latitude e/ou data de semeadura.

KIIHL (1976) e TISSELLI FO (1981) detectaram diferenças genēticas entre cultivares de soja quanto à duração do período juvenil, especialmente sob condições de dias curtos, fato este que abre possibilidades de sucesso na seleção para alterar este carāter.

No Estado de são Paulo, a soja também é cultiyada no inverno, em sucessão com o cultivo de verão representado, preferencialmente, por uma graminea (milho, sorgo) com ciclo precoce. No cultivo de inverno, a soja é semeada entre os meses de janeiro e março e é colhida nos meses de jü nho e julho, constituindo o que se denomina de "safrinha". 
Considerando as variações climāticas entre as estações de verão e inverno no Centro-sul do Brasil, para cultivos bem sucedidos de soja no inverno, são necessários cultivares adaptados às condições ambientais menos favoráveis, principalmente em termos de fotoperiodo mais curto e temperatura mais baixa.

A avaliação e seleção do germoplasma existente é de fundamental importância para o desenvolvimento de genótipos mais promissores e melhor adaptados. Assim sendo, este trabalho teve por objetivos:

a) avaliação das alterações ocorridas na produtividade e em outros caracteres de interes se agronômico sob condições de inverno, relativamente às condições de cultivo normal (verão), de modo a indicar aqueles menos sensiveis a fotoperíodos curtos e baixas tem peraturas;

b) estimar a influência da mudança de cultivo de verão para inverno sobre as estimativas dos parâmetros genēticos e fenotípicos importantes ao emprego da seleção. 


\section{REVISÃO DE LITERATURA}

\subsection{Classificacão das espécies quanto ao fotopertodo}

o efeito do fotoperíodo no florescimento é o aspecto mais intensamente pesquisado da influência da luz sobre a mudança dos padrões de crescimento durante o ciclo de vida das angiospermas. De acordo com HOWELL (1960), Moders foi o primeiro a perceber que o fotoperiodo poderia influenciar o florescimento e a importância de um periodo crítico de escuro foi reconhecida logo depois. Entretanto, foi o famoso trabalho realizado por GARNER \& ALLARD (1920) que atraiu a atenção do mundo para a intima relação entre fotoperiodo e muitos outros processos da planta, incluindo o florescimento. Estes autores classificaram as plantas de acordo com a sua resposta básica ao comprimento do dia em três categorias:

a) plantas de dias curtos (PDC) - são aquelas que florescem apenas quando o comprimento do período luminoso ou fotoperiodo é inferior a um periodo máximo chamado crítico, acima do qual não ocorre o florescimento.

b) plantas de dias longos (PDL) - aquelas que florescem quando o comprimento do período luminoso é maior que um mínimo chamado critico. 
c) plantas neutras ou indiferentes (PN) - aque las que florescem em qualquer comprimento do dia, ou seja, pa ra as quais o fotoperíodo não é o fator determinante do florescimento.

Recentemente, VINCE-PRUE (1975) dividiu cada uma das primeiras categorias em:

a) resposta fotoperiódica qualitativa ou absoluta, quando um comprimento de dia específico é essencial para a floração;

b) resposta fotoperiódica quantitativa, quando um comprimento de dia específico favorece a floração, mas não è essencial.

A soja é normalmente considerada uma planta de dias curtos. Todavia, atualmente já são conhecidos genótipos pouco sensiveis e até insensiveis ao compriménto do dia (SHAN MUGASUNDARUM et alii, 1980; SHIBES, 1980). Este fato permite o cultivo da soja de maneira economicamente viável em praticamente todas as latitudes.

\subsection{Fot Oper IODO E InDUGÃo FLORAL}

A soja é tida como uma planta extremamente sen sível ao comprimento do dia para se iniciar a indução floral. Nos idos de 1908, Moders segundo HOWELL (1960) em plantios sucessivos documentou variações quanto à duração do período vegetativo (período compreendido da germinação ao 
início do florescimento) de algumas variedades de soja. Posteriormente, GARNER \& ALLARD (1920) desenvolveram trabalhos com diversas espécies, visando compreender o comportamento des tas frente às variações do comprimento da luz do dia, culminando com o esclarecimento dos termos fotoperiodo (comprimento do dia favorável para cada organismo) e fotoperiodismo (res posta de um organismo ao comprimento relativo do dia e noite).

A partir de 1938, BORTHWICK \& PARKER realizaram sucessivos estudos sobre a influência do fotoperíodo no desenvolvimento da soja. Relataram que a indução da floração é uma característica própria e intrínseca dos genótipos e que a cultivar Biloxi evidencia, microscopicamente, primórdios flo rais três dias após ser submetida a dois dias de oito horas de luz, enquanto dez dias são suficientes para serem visualizados (BORTHWICK e PARKER, 1938a). Complementando o trabalho anterior, os mesmos autores (1938b) testaram o efeito de tratamentos fotoperiódicos na cultivar Biloxi em diferentes idades. Os resultados mostraram que o efeito dos tratamentos au mentou com a idade da planta. A razão para estas diferenças nas respostas dos tratamentos fotoperiódicos encontra-se provavelmente nas diferentes āreas foliares. Sugeriram ainda se rem as folhas, o órgão no qual o estímulo se origina, translocando-se para os pontos de reprodução (BORTHWICK \& PARKER, 1938c).

Continuando na mesma linha de pesquisa, BORTHWICK \& PARKER (1940) realizaram um estudo com o cultivar Bi- 
loxi, para avaliar a eficiência das folhas na iniciação floral, com relação à idade e posição. Concluiram que a folha mais eficiente para causar a iniciação floral è a que, recentemente atingiu o desenvolvimento completo. As folhas jovens vão aumentando sua capacidade de estimular o florescimento até atingirem o desenvolvimento completo; logo após, iniciam um declinio gradual em eficiência.

o estímulo que causa oflorescimento, produzido pelas folhas transloca-se no caule por toda a planta. Segundo EVANS (1969) a quantidade de substância produzida é pro porcional ao número de dias curtos recebidos. SHANMUGASUNDARUM et alii (1979) encontraram uma certa correlação entre quarı tidade de substância produzida e o número de folhas trifolióladas. Estes autores sugerem que para qualquer tipo de genótipo, sensivel ou não ao fotoperíodo, o total de substâncias pro duzida está diretamente ligado ao número de folhas trifoliadas.

SHANMUGASUNDARUM e TSOU (1978) realizaram estudo visando determinar o período crîtico anterior à indução do florescimento e o comprimento da fotoindução necessário para promover a antese. Não foi detectada nenhuma diferença entre os tratamentos ( 10 e 16 horas de $1 u z$ ), no tempo levado para florescer a linhagem insensivel. Notaram tambēm que a linhagem sensível não tinha sido afetada pela redução da mudança no período de luz de 16 a 10 horas, até 9 dias da germi nação. Quando submetidas a 10 horas de luz e levadas posteriormente a um período de 16 horas, atë 36 dias depois da gex 
minação não floresciam, indicando que a indução sō se manifestava 36 dias após a germinação. A este período no qual não ocorre a indução do florescimento, eles chamaram de fase juvenil da soja. KIIHL (1976) e TISSELLI Fo (1981) detectaram diferenças genéticas entre cultivares quanto a duração do período juvenil, especialmente sob dias curtos, justifican do a seleção para esta caracteristica.

A duração da fase juvenil reflete o grau de sensibilidade ao fotoperiodo. Quanto maior esta fase, menor sensibilidade apresenta o cultivar.

Estudando os efeitos da mudança em fotoperío dos depois da indução floral, JOHNSON et alii (1960) encontraram que a exposição artificial das plantas durante o florescimento, a fotoperiodos maiores do que aqueles que precederam o florescimento, resultaram em uma maior duração do período de florescimento. SHANMUGASUNDARUM e TSOU (1978) relataram que a retirada das plantas da fonte indutora antes de ser completada a indução provocava a reversão das plantas para o estádio vegetativo, interrompendo o florescimento. No en tanto, os primeiros botões formados, floresciam.

As cultivares diferem quanto às respostas a mu danças no fotoperiodo. Diversos autores verificaram que variações no fotoperíodo afeta com maior expressão os cultivares de ciclo longo (JOHNSON et alii, 1960; BYTH, 1968; ABEL, 1961; PANDEY et alii, 1977; HARTWIG, 1970; BOARD e HALL, 1984). o fotoperiodo usado na indução floral, afeta de maneira significativa a expressão de determinados caracte 
res. BYTH (1968) e HARTWIG (1070) relataram que diferenças nas respostas dos cultivares, não foram obtidas para o flores cimento em fotoperíodos inferiores a 12 horas. Isto indicou, que o comprimento mínimo do período escuro necessário para possibilitar a expressão das diferenças varietais, está compreendida entre 12 e 14 horas por dia.

A época de plantio influencia o inficio da indu ção ao florescimento. Para os genótipos adaptados a uma determinada latitude, a indução ao florescimento será retardada se a semeadura for realizada precocemente. Tal situação proporcio na um maior período vegetativo, antes do início da indução pe lo fotoperíodo normal. A indução ao florescimento precoce pode ser obtida pelo retardamento da semeadura em função do fotoperíodo normal. Estes aspectos são normalmente obtidos e realizados em experimentos de épocas de plantio.

\subsection{TEMPERATURA}

Alēm do fotoperíodo, a temperatura também influencia o florescimento da soja (VAN SCHAIK \& PROBST, 1958). Segundo os mesmos autores, a cleistogamia é frequente sob tem peratura abaixo de $200 \mathrm{C}$.

HOWELL (1960) cita inümeros autores que evidenciam serem as respostas dos cultivares de soja ao floresci mento, alterados por temperatura. A primeira observação desse efeito foi relatada por GARNER \& ALLARD (1930). 
Estudos sobre interação temperatura/fotoperiodo, concluíram que a temperatura é importante apenas em cultí vares pouco sensiveis ao fotoperiodo ou na ausência de resposta fotoperiódica (PANDEY, 1972; LAWN \& BYTH, 1973; HARTWIG, 1970; BOARD \& HALL, 1984).

Vários autores afirmam que as temperaturas du rante o período escuro são de maior importância que a duração da luz. A temperatura noturna è de fundamental importância para o crescimento e desenvolvimento da soja e afeta tanto a resposta fotoperiódica (PARKER \& BORTHWICK, 1943) quanto à morfologia da planta (THOMAS \& RAPER, 1978).

Uma mudança de $50 \mathrm{C}$ na temperatura noturna mantida durante todo o periodo de crescimento afetou de modo sig nificativo o crescimento vegetativo e reprodutivo de algumas cultivares de soja (HUXLEY \& SUMMERFIELD, 1974). Tanto o foto periodo quanto a temperatura noturna afetaram o tempo para florescimento, mas a taxa de crescimento vegetativo foi mais dependente da temperatura noturna, relativamente ao comprimento do dia ou à temperatura diurna.

Segundo SEDDIGH \& JOLLIFF (1984), a menor produção de sementes das plantas do tratamento de 24 OC em relação às do tratamento de $169 \mathrm{C}$ foi devido a uma substancial redu ção do crescimento vegetativo rias plantas submetidas ao trata mento de $24 \circ \mathrm{C}$.

Experimento conduzido por BOARD \& HALL (1984) avaliando os efeitos das combinações de temperatura/fotoperío do permitiu a constatação de que temperatura mais quente (270 C 
vs 2loc) reduziu o tempo para o florescimento de maneira mais eficaz sob indução de dias curtos e cultivares dos grupos de maturação VI e VII em comparação com as cultivares do grupo de matụ ração $V$.

Vale ressaltax que todos os estudos existentes na literatura foram realizados em ambientes controlados. Tais estudos são de valor limitado, uma vez que a resposta da plan ta pode ser confundida por muitos outros fatores ambientais, como por exemplo irradiação, fotoperíodo e temperatura média diāria, que geralmente são mantidas constantes nas câmaras de cultivo, enquanto mudam continuamente durante todo o período de crescimento em condições de campo.

\subsection{EPOCA DE PLANTIO}

O desempenho dos cultivares quando levadas a diferentes regiões daquelas para as quais elas foram desenvol vidas, sofrem ação ambiental, cujos efeitos condicionam a mor fologia e estrutura das plantas.

A resposta dos cultivares às variações de foto período podem ser observadas de duas maneiras: primeiro, procedendo-se à semeadura em uma época fixada e variando a latitude (plantios em locais diferentes); segundo, variando a épo ca de semeadura na mesma latitude (plantios no mesmo local).

A altura da planta de soja é considerada impor tante parâmetro em virtude de sua relação com a srodutividade 
controle de invasores, acamamento e eficiência na colheita me canizada. POLSON (1972), CRISWELL \& HUME (1972) observaram que a altura da planta no florescimento aumentou com o fotoperío do, o mesmo ocorrendo com o número de nós no caule.

Os trabalhos de HARTWIG (1954), OSLER \& CARTER (1954), ABEL (1961) evidenciaram que para proporcionar maior altura, a data ideal de plantio é um mês antes do dia mais longo do ano. Os plantios antecipados ou retardados com rela ção à data ideal diminuiu consideravelmente a altura, devido à ocorrência de florescimento precoce.

Os mais altos rendimentos nos Estados Unidos são obtidos normalmente em plantios realizados em início de maio (ABEL, 1961; MATSON, 1964). O florescimento prematuro induzido por dias curtos tem sido relatado como sendo um fator principal de redução da produção de grãos nas datas precoces de plantio (BOARD \& HALL, 1984; HARTWIG, 1954; BOARD, $1985)$.

De acordo com MASCARENHAS et alii (1968), em uma série de experimento no Estado de São Paulo, a melhor época para o plantio dos cultivares comerciais é a primeira quinzena de novembro.

Para as condições brasileiras, os experimentos realizados mostram que as épocas de plantio influenciaram a produção, sendo as respostas variāveis em função de local, ano do experimento e cultivar.

QUEIROZ et alii (1971) verificaram em Ponta Grossa, PR, que as semeaduras durante o mês de outubro e no 
início de novembro originaram as maiores produções. Em marin gá, PR, como resultado de quatro anos de pesquisa, observaram que os cultivares tardios produzem melhor quando semeados no final de outubro e os de ciclo médio, em novembro.

BERGAMASCHI et alii (1978) pesquisaram a produ tividade em Taquarí, RS. em experimentos semeados em 20/10; 04/11, 21/11 e 20/12. Foi detectado efeitos significativos para épocas, cultivares e interação épocas $x$ cultivares. GUIMARÃES et alii (1978) estudaram seis épocas de semeadura durante três anos agrícolas. No primeiro ano, a produção da primeira época foi maior que da última, e esta semelhante às demais. No segundo ano, as épocas não provoca ram diferenças na produtividade. No terceiro ano, a produção da semeadura de 14/11 foi superior às de 16/10, 14/11 e 29/12.

EMPINOTTI (1975) observou que ém doze épocas de semeadura, de $11 / 08$ a 01/01, as cultivares Davis e santa Rosa, produziram melhor nas semeaduras realizadas entre 21/09 a $01 / 12$. As semeaduras anteriores e posteriores a este perío do tiveram produções reduzidas.

Um número reduzido de nós, também tem sido observado em datas não adequadas de plantio (SHANMUSASUNDARUM \& TSOU, 1978; CONSTABLE, 19772.

Diversos autores (OSLER \& CARTER, 1954; JOHNSON et alii, 1960; ABEL, 1951; HARTWIG, 1970; LAWN \& BYTH, 1973) tem estudado os efeitos da época de semeadura sobre a duração do período vegetativo e do ciclo total, tendo sido constatadas respostas semelhantes, quais sejam: 
a) o número de dias da semeadura ao florescimen to e do florescimento à maturação da vagem é diminuído com o atraso na época da semeadura;

b) os intervalos entre as datas de semeadura são maiores do que os intervalos entre as datas de maturação;

c) as cultivares precoces apresentam menores variações quanto à duração total do ciclo.

o estádio reprodutivo é também jnfluenciado pe lo fotoperíodo, sendo sua duração em dias tanto maior quanto maior o fotoperíodo (JOHNSON et alii, 1960; ABEL, 1961; SHANMUGASUNDARUM \& TSOU, 1978).

\subsection{IDENT IFICAৎÃO DE GENOTTIPOS MENOS SENS IVEIS AO FOTOPERIODO}

O principal fator que controla o período de tempo da emergência à antese na soja é o comprimento do dia (GARNER \& ALLARD, 1930; JOHNSON et ali1, 1960). Consequentemente, a resposta ao fotoperíodo é um critério importante ao se determinar a latitude de adaptação da maioria dos genótipos de soja (HARTWIG, 19.73).

A produtividade dos cultivares americanas de soja cultivadas em condições de dias curtos (menos de 14 horas) geralmente tem sido limitada porque o florescimento e a subsequente fase reprodutiva são iniciadas antes da ocorrência de crescimento vegetativo adequado, resultando plantas com 
produção e altura inadequadas para colheita mecanizada.

Em condições de dias curtos, o crescimento ade quado provavelmente só é obtido em um genōtipo neutro ao fotoperíodo ou, alternativamente, em um genótipo com florescimen to retardado em condições de dias curtos.

Considerāvel esforço tem sido dedicado para identificar genōtipos insensiveis ao fotoperíodo. POLSON (1972) identificou introduções de plantas de soja dos grupos de matu ração 0 e 00 como supostamente neutras quando ao comprimento do dia, que floresciam entre 25-37 dias em fotoperiodos variando de 18 a 24 horas. Todavia o desempenho desses genōtipos em condições de fotoperíodos curtos é indefinido.

Dentre 111 genótipos de soja do grupo de matura ção 00,45 foram classificados como não sensiveis ao fotoperíodo (CRISWELL \& HUME, 1972). Em um fotoperíodo de 12 horas, os 45 genótipos mostraram tempo médio do plantio ao florescimento de 29,7 dias, indicando que esses genótipos apresentam florescimento precoce para serem utilizados sob condições de dias curtos.

GANDOLFI et alii (1977) estudaram a resposta de 555 genōtipos de soja pertencentes aos grupos de maturação VII, VIII, IX e X. Não detectaram nenhum cultivar completamen te insensível aos fotoperiodos estudados; porēm, identifica ram dois genótipos (PI 85416 e PI 95960) com pouca sensibilidade; estes genótipos são procedentes da Coréia e pertencentes ao grupo de maturação VII. 
De acordo com HUXLEY et alii (1974), GREGAN \& HARTWIG (1984) o cultivar Fiskely V mostrou-se fotoperiodicamente insensivel em termos de tempo para florescimento. Entretanto, apresentou altura mais alta e produziu mais vagens e sementes quando cresceu inicialmente em dias não indutivos. HARTWIG \& KIIHL (1979) identificaram dois genó tipos que floresceram e maduraram a 330 Lat. $N$ e que não apre sentaram florescimento extremamente precoce em condições de dias curtos, mas, ao contrário floresceram em aproximadamente 60 dias. Esses genótipos foram cruzados com cultivares adaptados ao Sul dos Estados Unidos. Os resultados indicaram que a característica de florescimento tardio em condições de dias curtos é recessiva, sendo controlada por poucos genes, podendo ser transferida em programas de melhoramento conduzidos sob condições de dias curtos.

NISSLY et alii (1981) indicaram a presença de uma sērie de genótipos do grupo de maturação III que poderiam ser classificados como não sensíveis ao fotoperíodo.

\subsection{Est IMAৎÃO DE fARÂMET ROS GENÉT I COS E FENOT IPICOS}

Coeficientes de determinação genotipica e de correlação fenotípica constituem parâmetros genëtico-estatisticos que caracterizam a variação genotípica e as associações entre caracteres. 
o termo coeficiente de determinação genotipica foi utilizado por FALCONER (1981) para designar o quociente entre a variação genotípica e a variação fenotipica. Ele tem sido utilizado por vários autores (FONSECA, 1978; MONTEIRO, 1980; MARTINS \& VELLO, 1981) para caracterizar a variabilidade de um conjunto fixo de genótipos, tais como uma série de cultivares; este conjunto fixo não representa uma popu lação referência, de maneira que não satisfaz as exigências para emprego do coeficiente de herdabilidade. o coeficiente de determinação genotípica tem sido simbolizado por "b" e tem uma interpretação semelhante à do coeficiente de herdabilidade no sentido amplo, pois ambos estão relacionados com a variação genotípica.

o coeficiente de determinação genotípica

varia de 0 a 1 . Quando toda a variância fenotipica for de natureza ambiental seu valor deve ser 0 ; deve assumir valor 1 quando toda a variância fenotípica for de natureza genotípica. Quando a sua estimativa é baseada em médias de repetições, a sua utilização fica resłrita ao tipo de experimento que levou à sua estimação; neste caso, não pode ser comparado com outros coeficientes obtidos de experimentos com estruturas dife rentes; esta comparação pode ser feita quando as estimativas são obtidas ao nível de plantas individuais (ACOSTA - ESPINOZA, 1983).

Diversos estudos tem procurado estimar a herdabilidade de alguns caracteres em soja (ANAND \& TORRIE, 1963; KNOW \& TORRIE, 1964; FEHR \& WEBER, 1968; SMITH \& WEBER, 1968). 
Os valores de herdabilidade variaram de 3 a $57 \%$ para produtividade; de 66 a $85 \%$ para altura da planta; de 43 a 75\% para acamamento; de 79 a $91 \%$ para tempo para maturação; de 76 a 91\% para tempo para florescimento; de 48 a $81 \%$ para período reprodutivo (ANAND \& TORRIE, 1963; KNOWN \& TORRIE, 1964).

Os estudos das correlações entre caracteres é de relevante interesse nos trabalhos de melhoramento, pois em geral se objetiva aprimorar os genótipos não para caracteres isolados mas, sim, para um conjunto de caracteres, através de seleção indireta praticada sobre caracteres desejāveis que estão associados positivamente.

HOWELL \& CALDWELL (1972) obtiveram estimativas de correlações positivas entre vārios caracteres em oito popu lações de soja: tempo para maturàção com produtividade, altura da planta e acamamento; altura da planta com acamamento. De acordo com GANDOLFI et alii (1977) e GARCIA (1979) os caracteres tempo para florescimento, altura da planta e número de nós também foram positivamente correlacionados entre si.

As associações de alguns caracteres morfolōgi cos com a produção de grãos foram pesquisadas por GASTAL \& VERNETTI (1979) em 25 cultivares (três grupos de maturação), na região de Arroio Grande, RS; detectaram correlações negati vas e significativas da produção de grãos com altura da planta e inserção da primeira vagem. Resultados contraditōrios para correlação entre altura da planta e produção de grãos são apre sentados por WEBER \& MOOTHY (1952), JOHNSON et alii (1955). Estes autores também verificaram correlaçōes positivas da prọ 
dução de grãos com tempo para florescimento, altura da planta, período reprodutivo e tempo para maturação; entre tempo para florescimento e altura da planta; do tempo para maturação com períodos reprodutivo e altura da planta; entre tempo para florescimento e maturação. Valores negativos de correlação foram observados entre tempo para florescimento e periodo reprodutivo. Tempo para maturação foi positivamente correlacionado com altura da planta em uma população e não correlacio nadas nas outras duas (WEBER \& MOOTHY, 1952), enquanto tais correlações foram negativas para as duas populações estudadas por JOHNSON et alii (1955).

Em estudos de gerações $F_{2}$ envoivendo seis popu lações de soja, TISSELLI Fo (1981) estimou correlações positivas entre tempo para florescimento e tempo para maturação; tempo para maturação e período reprodutivo. Tempo para florescimento foi negativamente correlacionado com período repro dutivo em quatro populações.

Para uma série de caracteres estudados em 10 cultivares de soja, em duas épocas de cultivo, GARCIA (1979) observou correlação positiva nas duas épocas para diversos caracteres, entre os quais: tempo para maturação com prođução de grãos, período reprodutivo, altura da planta, número de nós; entre altura da planta e altura de inserção da primeira vagem. As correlações obtidas entre periodo reprodutivo e al tura da planta com produção de grãos foram negativas para a época de cultivo considerada convencional para a região, mas foram positivas para a época considerada retardada. 


\section{MATERIAIS E MËTODOS}

Para atender aos objetivos propostos nesta pes quisa, foram conduzidos dois experimentos no setor de Genética Aplicada às Espécies Autógamas do Instituto de Genética da Escola Superior de Agricultura "Luiz de Queiroz" (ESALQ), em Piracicaba, SP.

As épocas de cultivo foram $07 / 11 / 85$ e 12/03/86.

A primeira representa a época de cultivo considerada convencional para a região, pois foi realizada dentro do período de 16 de outubro a 30 de novembro, que corresponde ao cultivo de verão. A segunda representa o cultivo de inverno.

As instalações dos experimentos foram idênticas nas duas épocas de cultivo. o preparo do solo constou de uma aração e duas gradagens. Com a finalidade de quebrar os torrões efacilitar a semeadura, foi passada uma enxada rotativa na área, três dias antes da instalação dos experimentos. o adubo foi distribuído no sulco de plantio, na base de 300 $\mathrm{kg} / \mathrm{ha}$ da fórmula $2: 30: 10$, que foi coberto com uma camada de terra.

As sementes de cada genótipo foram submetidas ao teste de germinação em incubadora B.O.D. regulada para tem 
peratura de $25 \circ \mathrm{C}$. Com base na percentagem de germinação calculou-se o número de sementes necessārio para obter o dobro do nümero de plantas recomendadas por metro linear de fileira. Aos 13 dias pós-emergência, procedeu-se ao desbaste para - estabelecimento da população inicial de plantas. Foram dei xadas 20 plantas por metro linear de fileira. Considerando que o espaçamento entre fileiras foi de $0,60 \mathrm{~m}$, obteve-se uma população de 333.333 plantas/ha.

Visando o controle de insetos sugadores e mastigadores, principalmente os percevejos Nezara viridula (L., 1958) e lagartas Anticarsia gemmatalis (Hubner, 1818), foram feitas aplicações de inseticiaa a base de Thiodan e Dipterex, alternadamente, sempre que se fizeram necessárias.

A duração do comprimento do dia, temperaturas médias, máximas e mínimas, umidade e precipitação durante a fase experimental, encontram-se no Apêndice 1.

Foram pesquisados 30 genótipos, compreendendo cultivares e linhagens experimentajs de soja: Biloxi, BR-9, BR-10, BR-11, BR.79-63, BR 80-14887, Cristalina, Doko, EMGOPA 301, GO 79-1039, GO 79-1084, IAC-5, IAC-6, IAC-8, IAC-9, IAC-11, IAC-12, Jüpiter, Numbaíra, OC 83-62, Paranagoiana, San ta Maria, Timbira, Tropical, UFV-I, UFV-2, UFV-3, UFV-4, UPV5, UFV-Araguaia.

Os dois experimentos foram delineados em blocos casualizados, com quatro repetições dos tratamentos. Os trinta tratamentos foram estratificados em dois conjuntos experimentais de quinze tratamentos (Tabela 1). Em cada conjunto 
foram incluídas três testemunhas comuns: IAC-8, IAC-12 e Tropical. As parcelas experimentais foram representadas por qua tro fileiras de 5,0 metros de comprimento; o espaçamento entre fileiras foi de 60 centímetros. Para a avaliação dos caracteres altura da planta e nümero de internódios, utilizaram se oito plantas competitivas dentro da ārea ūtil, as quais fo ram identificadas antes do florescimento permitindo, deste modo, a obtenção das observações nas mesmas plantas, tanto na época de florescimento como na maturação. Para avaliação da produtividade da parcela, considerou-se a área ūtil de $4,8 \mathrm{~m}^{2}$ formada pelos quatro metros centrais das duas fileiras intermediārias de cada parcela.

Durante todo o periodo experimental o solo foi mantido em condições de umidade satisfatōria, por meio de irrigações por aspersão, quando necessárias.

Os seguintes caracteres foram avaliados em cada época de cultivo:

a) tempo para florescimento ou período vegetativo - correspondente ao período entre a data da semeadura e a data em que havia flores abertas em qualquer nó de 50\% das plantas na parcela;

b) altura da planta no florescimento - compreendeu a distância da haste principal entre o colo e a inserção da inflorescência mais distal de oito plantas competitivas na área ütil da parcela;

c) nümero de internódios no florescimento - in cluiu todos os internödios da haste principal a partir do nó 
cotiledonar de oito plantas competitivas na área ütil da parcela;

d) tempo para maturação - compreendeu ao perío do entre a data da semeadura e a data em que 95\% das vagens da parcela alcançaram a maturação fisiológica;

e) altura da planta na maturação - representada pela distância da haste principal entre o colo e a inserção da vagem mais distal de oito plantas competitivas na área ütil da parcela;

f) acamamento - avaliado atravēs de uma escala de notas visuais, variando de 1 (todas as plantas eretas na parcela) a 5 (todas as plantas prostadas na parcela);

g) altura de inserção da primeira vagein - representada pela distância desde o colo até o ponto de inserção da vagem mais baixa;

h) nūmero de internōdios na maturação - foi adotado o mesmo procedimento relatado para a época de florescimento de oito plantas competitivas na ärea útil da parcela;

i) periodo reprodutivo - compreendeu o periodo de tempo entre o florescimento e a maturação, e calculado pela diferença entre o nümero de dias para maturação e para, o florescimento;

j) produção de grãos - compreendeu o peso das sementes de todas as plantas localizadas na área ütil de 4,8 $\mathrm{m}^{2}$ de cada parcela, transformada em $\mathrm{kg} / \mathrm{ha}$. 


\subsection{Tratamento estatíst I CO-genét I CO}

\subsubsection{Análises individuais e conjuntas da variância}

Com a finalidade de verificar a existência de efeitos ambientais entre os conjuntos experimentais, inicialmente realizaram-se análises de variância somente com as testemunhas comuns. Para cada época (verão e inverno) utilizouse o esquema da análise de variância da Tabela 2. A análise conjunta das duas épocas está representada na Tabela 3 . A seguir procedeu-se às análises de variância dos genótipos. Para os caracteres que não apresentaram interações significativas en volvendo o efeito de conjunto, empregaram-se os esquemas das Tabelas 4 e 5, para análise individual e conjuntas das duas ēpocas, respectivamente. Já para os caracteres que apresenta ram interações significativas, utilizaram-se os esquemas das Tabelas 6 e 7 .

\subsubsection{Estimativas de parâmetros genéticos e fenotípicos}

Tendo como objetivo estimar a proporção de variância fenotípica total entre os tratamentos (efeito fixo) que é de natureza genética, utilizou-se do coeficiente de determinação genotípica, conforme foi relatado na revisão de literatura. 
foi estimado para todos os caracteres em cada época de cultivo e para as duas épocas reunidas, utilizando-se da fórmula:

$$
b=\frac{\nabla g(\text { ou } \nabla g: c)}{\nabla g(\text { ou } \nabla g: c)+\sigma^{2}}
$$

Os componentes necessários para o cálculo do coeficiente "b" foram estimados a partir da análise da variân cia cujo esquema é baseado nas Tabelas 4 e 6 , fazendo-se:

$$
\hat{\nabla} g(\text { ou } \hat{\nabla} g: c)=\frac{Q_{3}-Q_{1}}{R}
$$

onde:

$Q_{1}$ : quadrado médio do resíduo;

$Q_{3}$ : quadrado médio de tratamentos (ou quadrado médio de tratamentos dentro de conjuntos), sem inclusão das testemunhas comuns dos experimentos;

$\sigma^{2}$ : variância experimental;

$\nabla g(o u \hat{\nabla g: c)}:$ componente quadrático da variação genotípica; R: número de repetições.

QForam estimados os coeficientes de correlação fenotipica entre todos os caracteres combinados dois a dois em cada época de cultivo e para as duas épocas reunidas, conforme förmula apresentada por FALCONER (1981). 


$$
r_{F(x, y)}=\frac{\operatorname{CoV}_{F(x, y)}}{\sigma_{F_{X}} \cdot \sigma_{F_{Y}}}
$$

onde:

$$
\begin{aligned}
& r_{F(x, y)}: \text { coeficiente de correlação fenotípica entre os }
\end{aligned}
$$

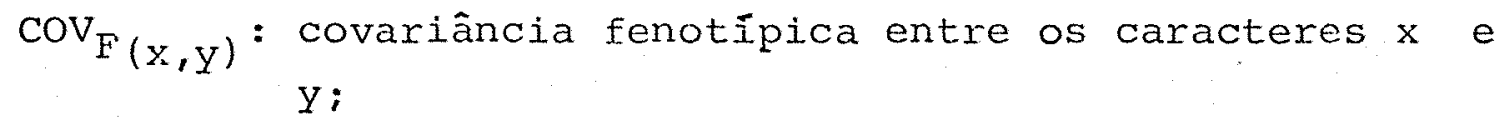

$$
\begin{aligned}
& \sigma_{F x} \text { e } \sigma_{F y} \text { : desvio padrão fenotípico dos caracteres } x \text { e } y \text {, }
\end{aligned}
$$

Os valores de $\operatorname{COV}_{\mathrm{F}(\mathrm{x}, \mathrm{y})}, \sigma_{\mathrm{Fx}}, \sigma_{\mathrm{FY}}$ foram estimados a partir das médias das repetições.

A metodologia anterior, também foi cmpregar da para estimar os coeficientes de correlação entre as duas épocas de cultivo para todos os caracteres avaliados.

A significância dos coeficientes de correlação fenotípica foi verificada pelo teste $t$, com $n-2$ graus de liberdade, aos niveis de $5 \%$ e $1 \%$ de probabilidade, segundo procedimento adotado por PIMENTEL GOMES (1985). 


\section{RESULTADOS E DISCUSSÃO}

A organização dos tratamentos (genōtipos) em conjuntos experimentais dentro de repetições (Tabela 1) ainda não é uma prática comum na experimentação relacionada com genética e melhoramento de soja no Brasil. Por esta razão, a apresentação dos resultados foi iniciada com as Tabelas 2 a 7 , que mostram os esquemas de análise de variância e as esperanças matemáticas dos quadrados médios deduzidas para este tipo de delineamento experimental. Estes esquemas diferem daqueles obtidos por VELLO (1985) porque este autor utilizou um de Iineamento no qual as repetições è que foram organizadas dentro de conjuntos experimentais:

Os resultados obtidos nas análises de variância realizadas com as testemunhas comuns são apresentados nas Tabelas 8 a 10. Os efeitos de conjuntos foram não significati vos tanto para os cultivos individuais como tambēm para os cultivos reunjdos. No entanto, nas anālises individuais de épocas, foram detectados efeitos significativos das interações entre conjuntos e testemunhas para os caracteres altura da planta no florescimento (verão e inverno), nümero de internó dios no florescimento (verão), tempo para maturação (verão), 
nūmero de internódios na maturação (verão) e altura da planta na maturação (inverno). Na anālise dos cultivos reunidos, a interação entre conjuntos e testemunhas só se mostrou significativa para os caracteres a I tura da planta no florescimento e número de internódios no flo rescimento. A interação entre conjuntos e épocas de cultivos não se mostrou significativa para nenhum carāter. A interação tripla envolvendo conjuntos, épocas e testemunhas mostrou -se significativa apenas para os caracteres altura da planta no florescimento e nümero de internódios no florescimento. Portanto, a estratificação dos tratamentos em conjuntos experimentais dentro das repetições mostrou-se eficiente para os dois caracteres laltura da planta no florescimento e número de internódios no florescimento), para os oito caracteres res tantes, os conjuntos puderam ser ignorados, de maneira a se obter delineamentos de blocos casualizados convencionais para os dois cultivos.

As Tabelas 11 a 13 mostram os resultados das a nálises de variância dos oito caracteres em que os conjuntos experimentais foram ignorados. Nestas tabelas, foram detectados efeitos significativos entre genōtipos e de interações ge nótipos $\mathrm{x}$ épocas de cultivo para todos os caracteres.

As Tabelas 14 e 15 resumem as anālises de variância dos caracteres altura da planta no florescimento e nū mero de internódios no florescimento, para os quais foi neces sário manter a estratificação dos tratamentos em conjuntos ex perimentais. Novamente, foram detectados efeitos significa- 
tivos entre genótipos e para interação genótipos $\mathrm{x}$ épocas de cultivo para os dois caracteres.

Conforme pode ser observado nas Tabelas II a 15, os coeficientes de variação experimental situaram-se dentro de níveis desejāveis de magnitude, pois variaram de $3,6 \%$ (período reprodutivo) a $23,1 \%$ (acamamento). Com exceção dos caracteres altura da planta na maturação e produção de grãos, os coeficientes de variação foram menores no cultivo de inver no relativamente ao cultivo de verão.

As médias (quatro repetições) dos 30 genōtipos, para os dez caracteres avaliados no verão e no inverno foram apresentadas nas Tabelas 16 a 25 . A Tabela 26 relaciona os coeficientes de determinação genotipica estimados para os dez caracteres. A Tabela 27 reporta os coeficientes de cor relação fenotípica entre os caracteres combinados dois a dois. A Tabela 28 mostra os coeficientes de correlação linear simples entre as auas épocas de cultivo para os dez caracteres a valiados. Tais resultados são discutidos a seguir.

\subsection{DUURAGÃO DOS ESTADIOS DA PLANTA}

O nümero de dias para início de florescimento tem sido um carāter dependente de inümeros fatores. Até recen temente, este caráter era considerado como sendo influenciado por três pares de genes. BERNARD (1971), identificou os genes $E_{1}$ e $E_{2}$, os quais controlam o início do florescimento e ma- 
turação sob condições de luz do dia ou de luz artificial incandescente. Assim quando este autor substitui o gene $e_{1}$ pelo $E_{1}$ no cultivar clark ocorreu um retardamento de 23 dias e 18 dias no florescimento e maturação respectivamente; o gene $\mathrm{E}_{2}$ ' quando substituido pelo alelo $e_{2}$ no mesmo cultivar, induziu a precocidade no florescimento em média de 7 dias e na maturação em cerca de 14 dias. O terceiro gene e 3 (BUZZEL, 1971) tem efeito principal no início do florescimento e maturação quando as plantas são crescidas sob condiçōes de luz fluorescente. As plantas possuidoras do alelo $\mathrm{E}_{3}$, terão retardado o início do florescimento quando sob uma condição de fotoperiodo longo de luz fluorescente. Atualmente mais genes $\left(e_{4} e_{5} e_{5}\right.$ são conhecidos influenciando o tempo para florescimento e para maturação. (PALMER et alii, 1987).

Genótipos com hābito de crescimento indeterminado cultivados no norte dos Estados Unidos, geralmente são relatados como possuidores do gene $e_{1}$ e de um fotoperiodo crí tico variāvel de 17 a 22 horas; para os genötipos possuidores de um fotoperiodo tão extenso, a temperatura seria o principal fator indutor do florescimento (SHIBLES, 1980); para tais genōtipos o florescimento somente ocorreria apōs o acúmulo de unidades de calor na planta (MAJOR et alii, 1975).

As comparações de médias pelo teste Tukey $(5 \%)$ apresentado na Tabela 16, evidenciaram que as médias do tempo para florescimento no inverno, foram significativamente inferiores aquelas observadas no verão, com exceção do cultivar Paranagoiana que, ao conträrio, apresentou tempo para flores- 
cimento oito dias mais tardio no inverno. Conforme destacado por KIIHL et alii (1984), o florescimento tardio em fotoperío dos curtos, como foi mostrado pelo cultivar paranagoiana, é devido a um par de alelos em homozigose, determinando adaptação ampla a vārias latitudes e épocas de plantio.

No cultivo de verão, o carāter tempo para florescimento oscilou de 59 a 96 dias, enquanto que no cultivo de inverno, esses valores foram de 33 a 73 dias, o que reflete um comportamento bastante variável dos cultivares nas duas épocas de cultivo. A influência do comprimento do dia no tempo para florescimento dos cultivares pode ser explicado atra vés de duas hipóteses.

A primeira hipötesc tem como base o comprimento do dia critico, o qual deve ser maior para os cultivares que floresceram mais rapidamente. $O$ espaço de tempo (número de dias) entre a emergêncià das plântulas e o momento em que o comprimento do dia atinge o limite crítico de indução ë maior no verão do que no inverno. Dessa maneira, no verão as plantas demoram mais para iniciar o florescimento e, consequentemente, tem desenvolvimento vegetativo maior do que no inverno.

A segunda hipötese diz respeito a existênciade um periodo juvenil diferente para os cultivares. Comparando se os valores apresentados na Tabela 16 , verificou-se que do cultivo de verão para o de inverno, as diferenças no tempo pa ra florescimento apresentados pelos cultivares oscilaram de 8 a 42 dias. Supõe-se que os cultivares com resposta menos 
sensivel ao fotoperíodo devem ter um periodo juvenil maior, ou seja, demoram mais dias para iniciar a resposta ao estimu10 fotoperiódico. A extensão do periodo juvenil de um cultivar, estaria relacionada com o número de genes para período ju venil presentes neste cultivar. De acordo com TISSELLI Fo (1981), até cinco genes poderiam estar envolvidos na expressão do período juvenil. Observou-se que os genótipos oc 87-63, BR 79-63 e IAC-8 apresentaram maior periodo juvenil em relação aos demais.

A utilização destes genótipos como parentais em programas de melhoramento para condições de inverno e/ou baixas latitudes seria uma estratégia promissora. A interação entre os genes que controlam o tempo para florescimento e para maturação $\left(e_{1}\right.$ a $\left.e_{5}\right)$ com os genes para período juvenil, ofe receria uma quantidade apreciável de variabilidade genética para o melhorista suplantar a diversidade de ambientes onde a soja poderia ser cultivada.

O comprimento do dia no inverno é mais curto do que no verão (Apêndice 1). Nestas condições, o tempo para florescimento foi menor em todos os cultivares. Este resultado já era esperado, pois dias curtos estimulam o florescimento em soja (ABEL, 1961).

As comparações de médias apresentadas na Tabela 17, demonstraram também que em cultivo de inverno, ocorreu uma redução no periodo reprodutivo para todos os cultivares, em relação ao cultivo de verão. A ređução no período reprodutivo devido à diminuição do comprimento do dia, jā tinha sido 
relatada nor JOHNSON et alii (1960). As reduções oscilaram de 1 a 40 dias. A influência do comprimento do dia na duração da fase reprodutiva foi menor nos cultivares IAC-6 e Tropical, que apresentaram reduções não significativas pelo teste de Tu彑 key a $5 \%$

Na Tabela 18, são apresentadas as comparações de médias do tempo para maturação dos cultivares. A apreciação dos resultados evidenciaram que no cultivo de inverno, tam bēm ocorreu uma redução significativa no tempo para maturação dos cultivares, com exceção do cultivar paranagoiana que apre sentou um prolongamento de dois dias.

A redução no tempo para maturação observada pạ ra a maioria dos cultivares, deveu-se a uma maior reduçäo no tempo para florescimento do que do período reprodutivo.

\subsection{Altura e número de internódios da planta no FLORESC IMENTO E MATURACÃO}

Nas Tabelas 19 e 20, observa-se que a época de cultivo fez variar a altura e o nümero de internódios no florescimento para todos os cultivares.

As comparações de médias pelo téste de Tukey a 5\% (Tabela 19) comprovaram que a altura da planta no inverno, foi significativamente inferior àquela observada no verão. Resultados concordantes foram encontrados por CRISWELL e HUME (1972) e CONSTABLE (1977) que verificaram que quanto 
maior o comprimento do dia, maior é a altura atingida pela planta no florescimento.

A amplitude de variação da altura dos cultivares foi de 59 a 138 centimetros no verão e de 26 a 94 centí metros no inverno. As maiores reduções na altura da planta do cultivo de verão para inverno foram registradas pelos cultivares Timbira, IAC-9, IAC-6, Doko e EMGOPA 301 com 85, 81, 76,75 e 74 centimetros respectivamente. As menores reduções foram apresentadas pelos cultivares IAC-8, Biloxi, Paranagoia na e IAC-12, respectivamente com 16, 17, 20 e 22 centímetros.

De modo semelhante ao observado para a altura da planta, o nümero de internódios no inverno sofreu uma redução significativa, com exceção do cultivar Biloxi, que apre sentou diferença não significativa. Segundo SHALiJGASUNDARUM et alii (1979), a altura é função do número de nós no caule. Neste estudo, o fato confirmou-se, uma vez que o coeficiente de correlação entre esses caracteres foi positivo e altamente significativos nas duas épocas de cultivo.

o cultivar Biloxi apresentou comportamento diferente nas duas épocas de cultivo, com relação a altura e nú mero de internódios da planta no florescimento. o número 'de internódios foi praticamente o mesmo no verão e inverno. No entanto, a altura da planta em cultivo de inverno sofreu significativa redução, sugerindo ocorrência de encurtamento dos internōdios.

No cultivo de verão, o nümero de internódios no florescimento variou de 12 a 22 , enquanto que no inverno foi 
de 7 a 19 internódios. Do cultivo de verão para o inverno, o cultivar UFV-5 foi o que apresentou a maior redução com 12 in ternódios. As menores reduções foram apresentadas pelos culti vares Biloxi, Paranagoiana e IAC-8 com 1, 2 e 3 internódios respectivamente.

Nas Tabelas 23 e 24 são apresentados os valores de altura da planta e nümero de internōdios na maturação respectivamente. Observou-se que a época de cultivo fez variar esses parâmetros nos cultivares.

As comparações de mëdias pelo teste de Tukey (5\%) revelaram que a altura da planta e o número de intemódios na maturação no inverno, foi significativamente inferior àquela observada no verão. Este resultado jā era esperado, pois as plan tas no florescimento apresentaram tambëm reduções significatị vas na altura e nümero de internódios.

Comparando-se os valores obtidos na altura da planta no florescimento (Tabela 19) com aqueles verificados na maturação (Tabela 23) observou-se que os cultivares apresentaram um crescimento da planta durante o período entre o florescimento e a maturação, nas duas épocas de cultivo. Esse crescimento variou de 5 a 66 centímetros no cultivo de verão e de 2 a 22 no inverno. Nos genōtipos UFV-Araguaia, Biloxi, OC 83-62, BR 80-14887, IAC-12, UFV-4, Paranagoiana, IAC-5 e IAC-8 cultivados no verão e no genótipo oC 83-62 cultivađo no inverno, o crescimento da planta foi conseguido pelo aumento do nümero de internódios após o florescimento, enquanto que 
nos demais genótipos, o crescimento da planta foi devido um alongamento dos internödios.

De acordo com BERNARD (1972), existem dois genes condicionando três tipos de häbito de crescimento em soja: indeterminado ( $D t_{1} D t_{1} d t_{2} d t_{2}$, determinado $\left(d t_{1} d t_{1} \ldots\right.$ ) e semi-determinado ( $D t_{1} D t_{1} D t_{2} e^{D} t_{1} d t_{1} \ldots$ ). Provavelmente, existem mais genes influenciando o hábito de crescimento. O próprio alelo $E_{1}$ que retaraa florescimento e maturação em soja também poderia estax relacionado com hábito de crescimen to, pois está presente na maioria dos cultivares de hábito de crescimento determinado desenvolvidos para o sul dos Estados Unidos (SHIBLES, 1980). Recentemente foi obtida distribuição aproximadamente normal para uma amostra de 522 genótipos, quando relacionou-se o número de internódios no florescimento e na maturação (KUENEMAN, 1986). Este autor sugeriu a substituição aa nomenclatura convencional (tipos de hábito de crescimentol pelo núméro de internódios no florescimento e na maturação. Este novo sistema seria mais apropriado para a representação de um carāter com herança quantitativa. Por esse sistema, o cultivar IAC-12 seria representado por (14, 16) no verão e $(10,10)$ no inverno; o cultivar IAC-5 seria representado por $(17,20)$ no verão e $(10,10)$ no inverno.

Sob condições de comprimento de dias curtos que causam maturação muito precoce, os cultivares de hábito de crescimento determinado e indeterminado tornam-se indistin guíveis (GANDOLEI et alii, 1983). Isto tambēm ocorreu na presente pesquisa (Tabelas 20 e 24), onde o cultivar UFV-4 tido 
como de hábito de crescimento indeterminado, comportou-se como determinado em cultivo de inverno.

\subsection{Acamamento}

Na Tabela 21 são apresentados os valores das mëdias de acamamento obtidos para as duas épocas de cultivo. Verificou-se que a maioria dos cultivares apresentaram graus diferentes de acamamento no cultivo de verão e inverno. Os maiores graus de acamamento foram verificados no cultivo de verão. Is to deveu-se a um maior tempo para florescimento e número de internódios alcançado pelos cultivares nesta época de cultivo, proporcionando maior altura da planta. No cultivo de inverno todos os cultivares apresentaram grau de acamamento mínimo, constituindo exceção o cultivar BR-10 que apresentou graú máximo de acamamento, fato indesejável do ponto de vista da pro dução e do manejo da cultura.

\subsection{Altura de inserৎÃo da PRimeira VAgem}

A apreciação dos resultados (Tabela 22) compro va que a época de cultivo influenciou a altura de inserção da primeira vagem. As maiores alturas de inserção, foram veri ficadas no cultivo de verão. Resultados semelhantes foram encontrados por DUTRA (1986), VILELA et alii (1978) que ve- 
rificaram maior altura de inserção da primeira vagem em época ideal de cultivo.

A amplitude de variação em cultivo de verão foi de 13 a 23 centimetros. Em cultivo de inverno variou de 9 a 22 centímetros. Os genótipos Biloxi, OC 83-62, Cristalina, IAC -11, BR 79-63, Paranagoiana, Tropical, EMGOPA 301, UFV-1 e BR 10 apresentaram diferenças não significativas de uma época em relação a outra.

Considerando como valores desejáveis a partir de 10 centímetros para a colheita mecanizada, muitos genötipos atingiram valores superiores em cultivo de inverno, constituindo exceções os cultivares Santa Maria e UFV-5 que apresentaram altura de inserção de 9 centimetros.

\subsection{ProduçãO DE GRÃOS}

Como pode ser constatado pela apreciação dos resultados (Tabela 25$)$, todos os genötipos sofreram significativas reduções na proautividade de grãos em cultivo de invernoem relação ao cultivo de verão.

A época de cultivo de inverno, considerada atra sada com relação a convencional (verão) causou uma diminuição na produtividade dos genótipos, devido ao menor tempo para flores cimento e altura da planta no florescimento, por efeito do comprimento do dia mais curto. Vários autores evidenciaram o mesmo tipo de comportamento da soja com relação a variação na 
época de semeadura (QUEIROZ et alii, 1971; LAWN e BYTH, 1973; EMPINOTTI, 1975; CONSTABLE, 1977; GUIMARÃES et alii, 1978).

Os coeficientes de correlação simples entre os caracteres são apresentados na Tabela 27. Verifica-se que no cultivo de inverno, houve correlação positiva e significativa entre a produção de grãos com tempo para florescimento e altura da planta no florescimento, fato que reforça os resultados encontrados neste trabalho. Este fato também vem ressal tar a importância de se utilizar esses parāmetros nos trabaIhos de seleção em condições de inverno ou de baixa latitude.

O melhor desempenho em cultivo de invermo, foi de monstrado pelo cultivar IAC-6, seguidos pelos cultivares Daranagoiana, BR-9, Doko, BR-10, Tropical, IAC-6, Cristalina e IAC-9, todos com produção acima de 2 t/ha.

A significância da interação épocas $x$ genótipos fez mudar a ordem dos genótipos nas duas épocas de cultivo. No cultivo de verão, o melhor desempenho em produção de grãos foi alcançado pelo cultivar Cristalina $(3873 \mathrm{~kg} / \mathrm{ha})$, en tretanto, este cultivar classificou-se em oitavo lugar no cul tivo de inverno com $2081 \mathrm{~kg} / \mathrm{ha}$ (Tabela 25). Já no cultivo de inverno, o melhor desempenho foi alcançado pelo cultivar IAC$8(2522 \mathrm{~kg} / \mathrm{ha})$, que no verão classificou-se em dēcimo sexto lugar com $2849 \mathrm{~kg} / \mathrm{ha}$. Destaque especial deve ser dado ao cultivar BR-9 (Savana) que alcançou níveis desejāveis de produti vidade $(3631 \mathrm{~kg} / \mathrm{ha}$ no verão e $2334 \mathrm{~kg} / \mathrm{ha}$ no inverno), classificando-se em terceiro lugar nas duas épocas de cultivo. A es tabilidade altamente favorável do cultivar BR-9 muito prova- 
velmente è consequência dos genes para período juvenil longo que ele herảou de seu ancestral PI 240.664; de fato, VELLo \& HIROMOTO (1986). mostraram que 25\% $(1 / 4)$ dos genes de BR-9 devem ser provenientes do ancestral PI 240.664, introduzidodas Filipinas via Estados Unidos e em uso no Brasil como fonte de genes para período juvenil longo;

\subsection{ESTIMATIVAS DE PARAMETTROS gENÉTICOS E FENOTÍPICOS}

As estimativas dos coeficientes de determinação genotípica (b) para os dez caracteres avaliados encontram - se na Tabela 26. Tais estimativas foram obtidas a partir das estimativas de componente da variância das análises apresenta das nas Tabelas 11, 12, 13, 14 e 15. Os valores relativamente altos destes coeficientes, indicam que parte significativa da variação fenotípica existente em todos os caracteres estudados é devida a causas genéticas.

Uma contribuição do coeficiente "b" é a possibilidade que ele oferece de comparar os níveis de variação existente em diferentes caracteres e/ou populações, de modo a predizer o grau relativo de dificuldade para alterar cada carāter através da seleção. 
Ficou enfatizado por FONSECA (1978), MONTEIRO (1980), MARTINS e VELLO (1981) que caracteres com valores de "b" próximos a 1 são poucos influenciados pelas condições de ambiente, sendo mais facilmente alterados pela seleção. Porém - sucesso na seleção, em todos os programas de melhoramento, depende, entre outros fatores, da magnitude da variância genética aditiva e da epistasia de tipo aditivo $x$ aditivo. A utilização do "b", semelhantemente ao da herdabilidade no sen tido amplo, deve ser cuidadosa, pois ambos medem a variação total, inclusive variância aditiva, dominante e epistáticos e nem todas são aproveitáveis na seleção.

De acordo com os valores de "b" (Tabela 26) ob servou-se que as estimativas para a maioria dos caracteres fo ram semelhantes nas três situações estudadas. Caracteres como tempo para florescimento, número de internódios no floresci mento e na maturação, altura da planta no florescimento e na maturação, tempo para maturação, acamamento e período reprodu tivo possuindo valores médios superiores para "b", seriam mais facilmente alterados por seleção; altura de inserção da primeria vagem e produção de grãos apresentariam grau intermediā rio de dificuldade à seleção.

As estimativas de "b" obtidas neste trabalho, - para o caráter produção de grãos, foram superiores aos valores de herdabilidade no sentido amplo obtidos por outros pesquisadores. Uma possível razão dessa diferença é a prōpria na tureza fixa do coeficiente "b", limitando a sua validade ao conjunto fixo de genótipos estudadas. Outra limitação é dada 
pelo próprio método utilizado para estimar "b", que baseau-se na parcela experimental empregada; consequentemente, as compa rações com valores obtidos por outros autores säo limitadas aos experimentos com delineamento, tamanho e tipo de parcelas semelhantes aos empregados nesta pesquisa. Esta limitação pode ser evitada quando o "b" é o estimado ao nível de plantas individuais; para tanto, há necessidade de se avaliar plan tas individuais dentro das parcelas experimentais e conduzir as anālises de variância tambēm ao nível de plantas individuais.

Os coeficientes de correlação fenotípica são de grande importância no melhoramento, pois podem orientar a seleção, principalmente no que se refere à intensidade a ser aplicada em cada caráter (VELLO et alii, 1973). Na Tabela27 são apresentados os coeficientes de correlação fenotipicas dos caracteres combinados dois a dois, obtidos para as duas épo cas de cultivo.

Comparando-se os resultados, observou-se que muitas das correlações fenotípicas obtidas a partir do experimento conduzido em cultivo de verão, foram também encontrados no experimento sob cultivo de inverno. Foram detectados correlações positivas e altamente significativas para os caracteres: tempo para florescimento com nūmero de internōdios no florescimento e maturação, altura da planta no florescimen to e maturação, tempo para maturação e acamamento; entre núme ro de internódios no florescimento e na maturação com altura da planta no florescimento e na maturação, tempo para matura- 
ção e acamamento; altura da planta no florescimento e na maturação com tempo para maturação e acamamento. Resultados semelhantes foram encontrados por WEBER e MOOTHY (1952), JOHNSON et alii (1955), HOWELL e CAIDWELL (1972), GANDOLFI et alii (1977), GARCIA (1979) e TISSELLI FO (1981). Os caracteres cujos coeficientes não apresentaram significância devem possuir pouca ou nenhuma associação, sugerindo que foram selecionadas independentemente ao longo do processo evolutivo da soja.

A produção de grãos apresentou correlação posi tiva e significativa com tempo para florescimento e altamente significativa com altura da planta em cultivo de inverno. A associação da produção de grãos com tempo para florescimento, e altura da planta torna-se importante no processo de obtenção de cultivares superiores em cultivo de inverno ou baixa latitude, porque permite usar esses caracteres como indicadores auxiliares nos trabalhos de seleção. No entanto, tais cor relações em cultivo de verão, apresentaram coeficientes negativos, discordando de resultados encontrados por WEBER e MOOTHY (1952), JOHNSON et alii (1955) e concordando com resulta dos obtidos por GASTAL e VERNETTI (1979), GARCIA (1979).

Entre o número de internódios e produção de grãos nas duas épocas de cultivo, praticamente não houve correlação, jā que o coeficiente encontrado foi baixo, mostrando uma ligeira tendência positiva. Estes resultados sugerem a independência dos caracteres, contrariando resultados verificados por GANDOLFI et alii (1977) e GARCIA (1979), que detectaram correlações positivas e significativas, demonstrando que 
houve tendência no sentido de que os cultivares com maior pro dução de grãos teriam maior número de internódios ou nós. Os coeficientes de correlação entre épocas para os caracteres individualmente, são apresentados na Tabela 28. Produção de grãos, acamamento e periodo reprodutivo apre sentaram coeficientes de correlação não significativos, haven do uma ligeira tendência positiva. Esses resultados indicam que os cultivares apresentaram maior variação para estes caracteres com relação às épocas de cultivo; portanto, para estes três caracteres, a seleção deve ser feita com base em experimentos conduzidos na época especifica em que os descenden tes serão cultivados. Foram detectadas correlações positivas e significativas para tempo para florescimento, tempo para ma turação, altura de inserção da primeira vagem, altura da plan ta no florescimento e na maturação e nümero de internódios no florescimento e na maturação; para estes caracteres, os resultados obtidos em uma época podem ter alguma validade para seleção de genótipos apropriados para cultivo na outra épo ca. 


\section{CONCLUSÕES}

a) As épocas de cultivo influenciaram a duração dos estádios de desenvolvimento dos cultivares, provocando reduções maio res no tempo para florescimento e menores no período repro dutivo dos cultivares no inverno.

b) A duração do tempo para florescimento e a altura da planta no florescimento são caracteres importantes em programasde melhoramento para maior produtividade em cultivo de inverno ou em baixas latitudes.

c) Tempo para florescimento, número de internódios, altura da planta, tempo de maturação, acamamento e período reprodutivo são mais facilmente alterados por seleção do que os caracteres altura de inserção da primeira vagem e produção de grãos.

d) A seleção para produtividade, acamamento e periodo reprodutivo deve ser feita na ëpoca especifica em que se pretende cultivar a descendência. Já para os caracteres tempo para florescimento, tempo para maturação, altura de inserção da primeira vagem, altura da planta no florescimento e 
na maturação, número de internódios no florescimento e na maturação, há possibilidade de se utilizar observações de uma época na seleção para outra época de cultivo.

e) Os genótipos Cristalina, UFV-Araguaia, BR-9, UFV-4 e UFV-2 apresentaram-se como as melhores opções de cultivo no verão, enquanto que no cultivo de inverno os genótipos IAC8, Paranagoiana, BR.9, Doko, BR-10 mostraram bom desempenho produtivo.

f) A incorporação de genes para periodo juvenil longo nos cul tivares mostrou-se ser uma estratégia promissora para sobre pujar a interação pronunciada entre o comportamento dos ge nótipos e as épocas de cultivo, de maneira a tornar possí vel que um mesmo genótipo tenha comportamento superior e relativamente estável em épocas diferentes de cultivo. 


\section{REFERENACIAS BIBLIOGRAFICAS}

ABEL, G.H. Response of soybeans to dates of planting in the Imperial Valley of California. Agron. J., Madison, 53: 959,1961 .

ACOSTA-ESPINOZA, J. Eficiência de policruzamento para recombi nação gênica e estimação de parâmetros genéticos em mandio ca (Manihot esculenta Crantz). Piracicaba, 1983, 79p. (Mes trado - Escola Superior de Agricultura "Luiz de Queiroz"/ USP).

ANAND, S.C. \& TORRIE, J.H. Heritability of yield and other traits and inter-relationships among traits in the $\mathrm{F}_{3}$ and $\mathrm{F}_{4}$ generations of three soybean crosses. Crop Sci. Madison, 3 : $508-11,1963$.

BEATTY, K.D.; ELDRIDGE, I.L.; SIMPSON JR, A.M. Soybean response to different planting patterns and dates. Agron. J., Madison, $\underline{74}: 859-62,1982$.

BERGAMASCHI, H.A.; BERLATO, M.A.; GONÇALVES, H.M.; SUTILI, J. R.; ROCCHI, C.E.; MATZENAUER, R. Ensaio nacional de ecolo gia; grupos de maturação. IPAGRO inf., Porto Alegre, I8: $32-7,1978$.

BERNARD, R.L. Two major genes for time of flowering and matuturity in soybeans. Crop. Sci:, Madison, 11: 242-4, 1971. 
BERNARD, R.L. Two genes affeting stem termination in soybeans. Crop Sci., Madison, 10: 235-9, 1972.

BOARD, J.E. Yield components associated with soybean yield reductions at monoptimal planting dates. Agron. J., Madison, 77: 135-40, 1985 .

BOARD, J.E. \& HALL, W. Premature flowering in soybean yield reductions at monoptimal planting dates as influenced by temperature and photoperiod. Agron. J., Madison, 76: 7004. 1984.

BORTHWICK, H.A. \& PARKER, M.W. Influence of photoperiods upon the differentiation of meristems and the blossoming of biloxi soybeans. Bot. Gaz., Chicago, 99: 825-39, 1938a.

BORTHWICK, H.A. \& PARKER, M.W. Effectiveness of photoperiod treatments of plants of different age. Bot. Gaz., Chicago, 100: $245-49,1938 \mathrm{~b}$.

BORTHWICK, H.A. \& PARKER, M.W. Photoperiodic perception in biloxi soybeans. Bot. Gaz., Chicago, 100: 374-87, 1938c.

BORTHWICK, H.A. \& PARKER, M.W. Floral initiation in Biloxi soybean influenced by age and position of leaf. Bot. Gaz., Chicago, 101: 806-17, 1940 .

BUZZEL, R.I. Inheritance of a soybean flowering response to fluorescent-daylenght condition. Can. Jour. Gen. Cytol., Otawa, 13: 703-7, 1971 .

BYTH, D.E. Comparative photoperiodic responses to several soybean varietes of tropical and temperature origin. Australian Journal of Agricultural Research, East Melburne, 19: 879-90, 1968 . 
CARTER, J.L. Detailed yield analysis of the effect of different planting dates on seven soybean varietes. IOWA St.J. Res., Ames 48: 291-310, 1974 .

CARTER, T.L. \& BOERMA, H.R. Implications of genetype planting date and row spacing interactions indouble-cropped soybean cultivar development. Crop Sci., Madison, 19: 607-10, 1979.

CONSTABLE, G.A. Effect of planting date on soybeans, in the nomoi Valley, New South walles. Aust. Jour. of Exp. Agric. and Amim. Husb. Melbourne, 17: 148-55, 1977.

CRISWEL, J.G. \& HUME, D.J. Variation in sensitivity to photoperiod among early maturing soybean atrains. Crop. Sci., Mauison, 12: 657-60, 1972 .

DUTRA, J.H. Comportamento de quinze genótjpos de soja (Glycine $\max$ (L.) Merri11), em diferentes épocas de plantio em Capinópolis, Minas Gerais. Minas Gerais, 1986. 59 p. (M.S. Universidade Federal de Viçosa).

EMPINOTTI, C.M. Ensaio de época de plantio; observações compa rativas entre épocas de plantio, rendimento unitário e qua lidade do produto em diferentes zonas fisiogräficas do Estado. Palatina, Estação Experimental de Palatina, 1975. p. 68. (Circular da Secretaria de Agricultura do Paraná).

EVANS, L.T. Crop physiology; some case histories. London, Cam bridge University Press, 1975.

FALCONER, D.S. Introduction to quantitative genetics. 2 . ed. London, Longman, 1981. 340 p. 
FEHR, W.R. \& WEBER, C.R. Mass selection by seed size and specific gravity in soybean populations. Crop. Sci., Madison, 8: $551-4,1968$.

FONSECA, T.C. Estimação de parâmetros visando a seleção de híbridos artificiais de amoreira (Marus alba L.). Piracica ba, 1978. 51 p. (Mestrado - Escola Superior de Agricultura "Luiz de Queiroz"/USP).

GANDOLFI, V.H.; MÜLLER, L.; MINOR, H.C.; BERLATO, M.A. Identi ficação de cultivares de soja (Glycine max. (L.) Merrill) me nos sensiveis ao fotoperiodo entre cultivares tardios. Agro nomia Sulriograndense, Porto Alegre, 13 (I): 63-82, 1977.

GANDOLFI, V.H.; BÃN, A.D.; VILHORDO, B.W. ; MÜLLER, L. Morfologia, anatomia e desenvolvimento. In: VERNETTI, F.J. Soja; planta, clima, pragas, moléstias e invasoras. Campinas, FUN DAÇÃO CARGILL, 1983. v.1, cap. 2, p. 17-89.

GARCIA, A. Estudo do indice de colheita e de outras caracte rísticas agronômicas de dez cultivares de soja (Glycine $\max ($ L.) Merrill) e suas correlações com a produção de grãos em duas ēpocas de semeadura. Viçosa, 1979. 76 p. (M. S. - Universidade Federal de Viçosa).

GARNER, W.M. \& ALIAARD, H.A. Effect of the relative longht of day and night and other factor of the enviroment on growth and reproduction in plants. Jour. of Agr. Research, Washington, $18(2): 553-607,1920$.

GARNER, W.M. \& ALLARD, H.A. Photoperiodic responses of soybeans in reation to temperature and other enviromental factores. Jour. Agr. Research, Washington, 41(10): 719-35, 1930 . 
GASTAL, M.F.C. \& VERNETTI, F.J. Correlação da produção com características morfológicas em soja. In: SEMINÁRIO NACIO NAL DE PESQUISA DE SOJA, 1., Londrina, 1978. Anais. Londri na, EMBRAPA/CNPSO, 1979. p. 365-75.

GREGAN, P.B. \& HARTWIG, E.E. Characterization of flowering response to photoperiod in diverse soybean genotypes. Crop. Sci., Madison, 24: 659-62, 1984 .

GUIMARÃES, J.A.P.; ARANTES, N.E.; RIOS, G.P. Respostas de alguns cultivares de soja a diferentes épocas de plantio, no município de Uberaba, M.G. In: EPAMIG. Relatório 75/76; projeto soja. Belo Horizonte, 1978. p. 114-31.

HARTWIG, E.E. Factors affecting time of planting soybeans in the southern states. Washington, USDA, 1954. $13 \mathrm{p}$.

HARTWIG, E.E. Growth and reproductive characteristics of soybean (Glycine $\max$ (L.) Men.) grow under short day condi tions. Trop. Sci., London, 12: 47-53, 1970.

HARTWIG, E.E. Varietal development. In: CALDWELL, B.E. ed. Soybeans; improvement, production and uses. Madison, Amer. Soc. Agron., 1973. cap. 6, p. 187-207.

HARTWIG, E.E. \& KIEHL, R.A.S. Identification and utilization of a delayed flowering charater in soybeans for short day conditions. Field crops res., 2: 145-51, 1979.

HOWELL, R.W. Physiology of the soybean. Adv. Agron. Orlando, 12: $265-310,1960$. 
HOWELL, R.W. \& CALDWELL, B.E. Genetics and other biological characteristics. In: SMITH, A.K. \& CIRCLE, S.J. Soybeans; chemistry and technology. Westport, AVI, 1978. p. 27-60.

HUXLEY, P.A. \& SUMMERFIELD, R.J. Effects of night temperature and photoperiod on the reprodutive antogeny of cultivars of cowpea and of soybean selected for the wet tropics. Plant Sci. Lett., Amsterdan, 3: 11-7, 1974.

JOHNSON, H.W.; BORTWICK, H.A.; LEFEEL, R.C. Effects of photoperiod and time of planting on rates of development of the soybean in various stages of the life cycle. Bot. Gaz., Chicago, 122: 77-95, 1960.

JOHNSON, H.W.; ROBINSON, H.F.; COMSTOCK, R.E. Genotypic and phenotypic correlations in soybeans and their implications in selection. Agron. J., Madison, 47: 477-83, 1955.

KIIHL, R.A. de S.i Inheritance studies of two characteris in soybean (Glycine max (L.) Merrill); I. Resistence to soybean mosaic virus. II. Late flowering under short day conditions. Mississipi, 1976. 56 p. (Ph.D. - Mississipi state University).

KIIHL, R.A.S.; COSTA, A.V.; BAYS, I.A.; ALMEIDA, L.A.; GARCIA, A. Cultivar de soja paranagoiana. In: SEMINĀRIO NACIONAL DE PESQUISA DE SOJA, 3., Campinas, 1984. Anais. Lon drina, EMBRAPA/CNPSO, 1984, p. 473.

KUENEMAN, E.A. Soybean breeding. Goiânia, 1986. Ip. (Palestra apresentada na Reunião de Pesquisa de Soja da Região Central do Brasil, Goiânia, 1986).

KWON, S.H. \& TORRIE, J.H. Heriability of and interelationship among traits of two soybean population Crop Sci., Madison, 4: 196-8, 1964 . 
LAWN, R.J. \& BYTH, D.E. Response of soybeans to planting dates in Southeastern Quinsland; I. Influence of photoperiod and temperature or phasic development patterns. Aust. J. Agric. res., Melbourne, 24: 67-80, 1973.

MAJOR, D.J.; JOHNSON, D.R.; LUEDDERS, V.D. Evaluation of eleven thermal unit methods for proceding soybean development. Crop. Sci., Madison, 15: 172-9, 1975.

MARTINS, P.S. \& VELLO, N.A. Performance and variability of agronomic characters in populations of stylosantes guianen sis (Aubl.) sw. In: INTERNATIONAL GRASSLAND CONGRESS, 14, Kentucky, 1981. Proceedings. s.n.t. p. 196-8.

MASCARENHAS, H.A.A.; MIYASAKA, S.; KIIHL, R.A.S.; DEMATTE, J. D. Instruções para a cultura de soja. Campinas, IAC, 1968. 48 p. (Boletim Técnico, 22).

MATSON, A.L. Some factors affecting the response of soybean to irrigation. Agron. J., Madison, 56(6): 552-6, 1964.

MONTEIRO, W.R. Estudo da variabilidade e conclusão entre caracteres agronômicos em populações de centrosema pubescens Benth. Piracicaba, 1980. 70 p. (Mestrado - Escola Superior de Agricultura "Luiz de Queiroz"/USP).

NISSLY, C.R.; BERNARD, R.L.; HITTLE, C.N. Variation in photoperioa sensitivity for time of flowering and maturity amons soybean strains of maturity group III. Crop sci., Madison, 21: $773-6,1981$.

OSLER, R.D. \& CARTER, J.L. Effect to planting date on chemical composition and growth characteristics of soybean. Agron. J. Madison, 46 (6): 367-70, 1954. 
PALMER, R.G.; SHOEMAKER, R.C.; RENNIE, B. Approved soybean gene symbols. Soybean Genetic Newsletter, Ames, 14: 41-58, 1987.

PANDEY, R.K. Photoperiodic and temperature effects on flower initiation of diverse genotypes of soybeans (Glycine max (L.) Merr. Urbano. Illinois, 1972. (PhD. University of Illinois).

PANDEY, R.K.; LENG, E.R.; JACDBS, J.A. Path-coefficient analy sis of flowering time in diverse genotypes of soybean as influenced by temperature and douylenght. Indian J.Agric. Sci., New Delhi, 47(10): 498-502, 1977.

PARKER, M.W. \& BORTHWICK, H.A. Influence of temperature on photoperiodic reactions in leaf blades of biloxi soybean. Bot. Gaz., Chicago, 104: 612-9, 1943.

PASCALE, A.J. Tipos agroclimaticas para el cultivo de la soja en la Argentina. Reviste de la faculdade de Agronomia $y$ ve terinária de Buenos Aires, Buenos Aires, 17(3): 31-8, 1969.

PIMENTEL GOMES, G. Curso de Estatística experimental. 11. ed. São Paulo, Nobel, 1985. 466p.

POLSON, D.E. Day-neutrality in soybean. Crop. Sci., Madison, 12: $773-6,1972$.

QUEIROZ, E.F.; TERASAWA, F.; KASTER, M. Fitotecnia. Porto Ale gre, Instituto de Pesquisa Agropecuária Meridional, 1971. 12 p. (Circular, 9).

SEDDIGH, M. \& JOLLIFF, G.D. Effects of night temperature on dry motter partitioning and seed growth of indeterminate fielsgrown soybeans. Crop. Sci., Madison, 24: 704-10, 1984. 
SHANMUGASUNDARUM, S. Variation in the photoperiodic response to flowering in soybeans; Soybeans Genet. Neel., Ames, 5 : $91-4,1978$.

SHANMUGASUNDARUM, S. \& TSOU, S.C.S. Photoperiod and critical duration for flower induction in soybean, Crop. Sci., Madi son, 18: 559-601, 1978 .

SHANMUGASUNDARUM, S.; CHAO-CHIN, W.; TOUNG, T.S. Photoperiodic response of flowering in Two-bramhea soybean plants. Bot. Gaz., $140(4): 414-17,1979$.

SHANMUGASUNDARUM, S.; KNO, G.C.; NALAMPANG, A. Adaptation and utilization of soybeans in different enviroments and agri cultural systems. In: INTERNATIONAL LEGUME CONFERENCE, Kew, 1978. Advances in legume Science; proceedings. Kew, Royal Botanic Gardem, 1980. p. 265-77.

SHIBLES, R. Adaptation of soybeans to different seasonal durations. In: INTERNATIONAL LEGUME CONFERENCE, Kew, 1978. Advances in legume science; proceedings. Kew, Royal Bótanic Gardens. 1980. p. 279-86.

SMITH, R.R. \& WEBER, C.R. Man selection by specifie gravity for protein and soil in soybean populations. Crop. Sci., Madison, 8: $373-7,1968$.

THOMAS, J.F. \& RAPER JR, C.D. Morphological response of soybean as governed by photoperiod, temperature and age at treatment. Bot. Gaz., Chicago, 138(3): 321-8, 1977.

THOMAS, J.F. \& RAPER JR., C.D. Effect of day and night temperatures during floral induction an morphology of soybeans. Agron. J.; Madison, $\underline{70}(5)$ : 893-8, 1978. 
TISSELLI FO., O. Inheritance study of the long-juvenile characteristic in soybeans under long-and short-day conditions. Mississipi. 1981. 77p. (Doctor-Daculty of Mississipi State University).

VAN SCHAIK, P.H. \& PROBST, A.H. Effects of some enviromental factor on flower production and reproductive efficiency in soybean. Agron.J., Madison, 50: 192-7, 1958.

VELLO, N.A. Efeitos da introdução de germoplasma exótico so bre a produtividade e relações com a base genētica das cul tivares de soja (Glycine max (L.) Merrill). Piracicaba, 1985. 9lp. (Livre-Docência - Escola superior de Agricultu ra "Luiz de Queiroz"/USP).

VELLO, N.A. \& HIROMOTO, D.M. Base genética e desenvolvimento de cul tivares de soja (Glycine max (L.) Merrill) no Brasil. In: SEMINA RIO NACIONAL DE PESQUISA DE SOJA, 4., Porto Alegre, 1986. Mimeografa do, $20 \mathrm{p}$.

VELLO, N.A.; VENCOVSKY, R.; GERALDI, I.O. Correlações genēti cas e fenotípicas, respostas correlacionadas, ganho espera do na seleção e herdabilidade de alguns caracteres em capim gordura (Melinis minutiflora Beauv.). Relatōrio Científico do Depar tamento de Genética, Piracicaba, 7: 208-17, 1973.

VILELA, L.; SPEHAR, C.R.; SOUZA, P.I.M.; VIEIRA, R.D. Comportamento de cultivares de soja em época seca (inverno) no cerrado do Distrito Federal. In: SEMINARIO NACIONAL DEPES QUISA DE SOJA, 1., Londrina, 1978. Anais. Londrina, EMBRA $\mathrm{PA} / \mathrm{CNPSO}$, 1979 , p.357-63.

VINCE-PRUE, D. Photoperiodism in plants. Maidenhead, MCGrow -Hill Book, 1975. 444p.

WEBER, C.R. \& MOOTHY, B.R. Heritable and nonheritable relationships and variability of soil content and agronomie characteres in the $\mathrm{F}_{2}$ geration of soybean crosses. Agron. J., Madison, 44: 202-9, 1952. 
57.

$\underline{T} \underline{A} \underline{B} \underline{E} \underline{\mathrm{L}} \underline{\mathrm{A}} \underline{\mathrm{S}}$ 
Tabela 1. Esquema ilustrativo da instalação dos dois expeximentos com tratamentos estratificados em conjuntos experimentais dentro de repetições. Cada conjunto experimental compreendeu 15 tratamentos e três testemunhas comuns. Soja, Piracicaba, 1985 e 1986.

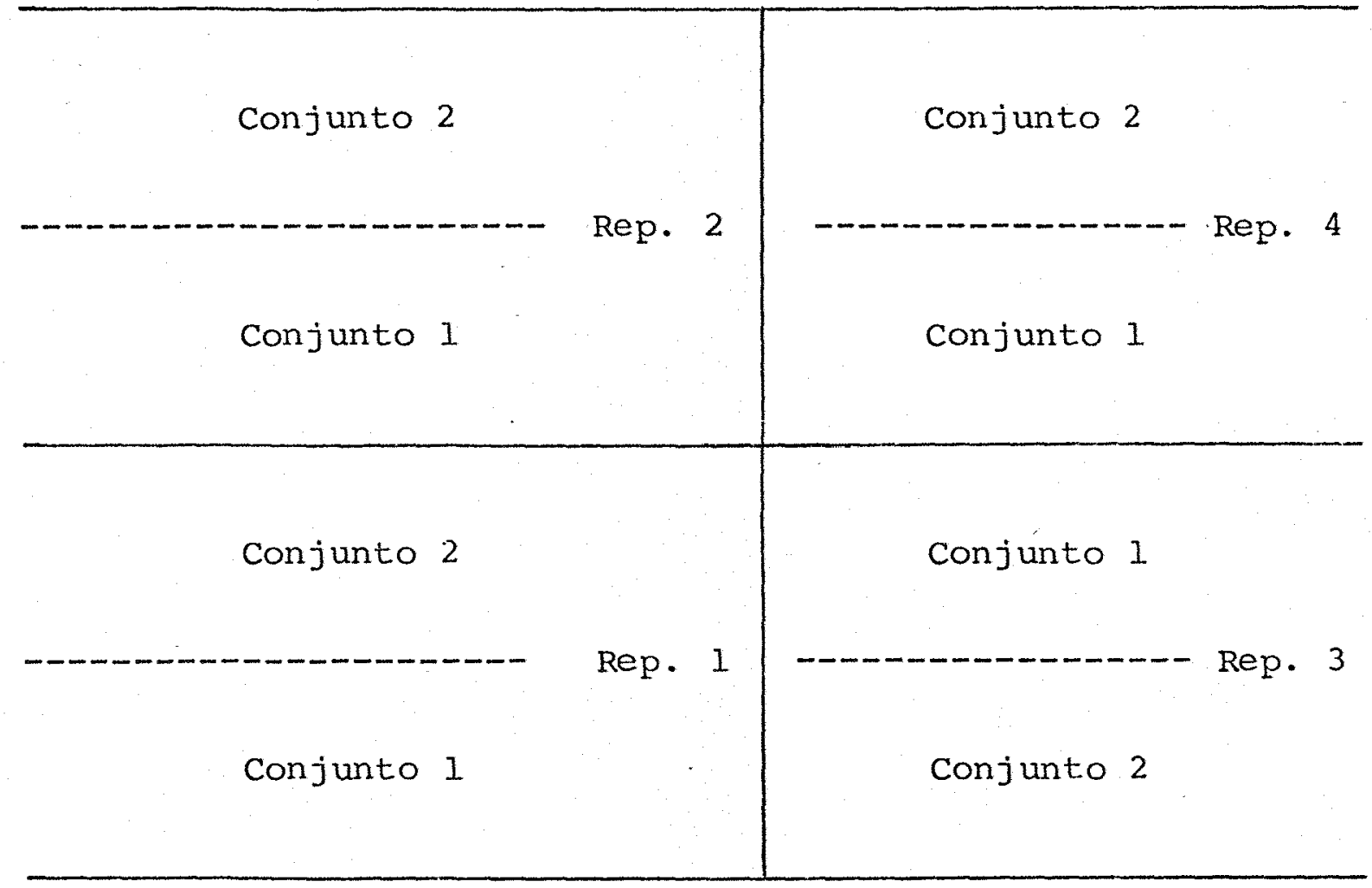

Conjunto 1: UFV-Araguaia, IAC-6, Biloxi, OC 8362, BR-80-14887, Cristalina, IAC-12, $\mathrm{BR}-9$, IAC-11, BR-11, UFV-3, Tim bira, UFV-4, IAC-9, BR 79-63.

Conjunto 2: Numbaíra, Go 70-1084, Paranagoiana, Tropical, Doko, Jūpiter, IAC-5, Santa Maria, IAC-8, EMGOPA 301, GO 79-1039, UFV-2, UFV-1, UFV-5, BR-10. 
Tabela 2. Esquema de análise de variância para as testemunhas, com as esperanças matemáticas dos quadrados médios.

\begin{tabular}{|c|c|c|c|c|}
\hline $\begin{array}{l}\text { Fontes de } \\
\text { variação }\end{array}$ & GL & $\mathrm{QM}$ & $E(Q M)$ & $\mathrm{F}$ \\
\hline Repetições & $R-1$ & $Q_{5}$ & $\sigma^{2}+C T \sigma_{r}^{2}$ & $\mathrm{Q}_{5} / \mathrm{Q}_{1}$ \\
\hline Conjuntos (C) & $C-1$ & $\mathrm{Q}_{4}$ & $\sigma^{2}+R T \sigma_{C}^{2}$ & $Q_{4} / Q_{1}$ \\
\hline Testemunhas $(\mathrm{T})$ & $T-1$ & $\mathrm{Q}_{3}$ & $\sigma^{2}+R \sigma_{C t}^{2}+C R V_{t}$ & $Q_{3} / Q_{2}$ \\
\hline $\mathrm{C} \times \mathrm{T}$ & $(C-1)(T-1)$ & $\mathrm{Q}_{2}$ & $\sigma^{2}+r \sigma_{c t}^{2}$ & $Q_{2} / Q_{1}$ \\
\hline Resĩduo & $(T C-I)(R-I)$ & ${ }^{Q_{1}}$ & $\sigma^{2}$ & \\
\hline TOTAL & TCR-1 & & & \\
\hline
\end{tabular}


Tabela 3. Esquema de anālise de variância conjunta para épocas de cultivo das testemunhas com as esperanças ma temáticas dos quadrados médios.

\begin{tabular}{|c|c|c|c|c|}
\hline $\begin{array}{l}\text { Fontes de } \\
\text { variação }\end{array}$ & GL & $Q M$ & $E(Q M)$ & $\mathrm{F}$ \\
\hline Epocas (E) & $E-1$ & $Q_{9}$ & $\sigma^{2}+C T \sigma_{b: e}^{2}+R T \sigma_{e c}^{2}+R C T V_{e}$ & $\frac{Q_{9}+Q_{1}}{Q_{2}+Q_{4}}$ \\
\hline Conjuntos (C) & $C-1$ & $\mathrm{Q}_{8}$ & $\sigma^{2}+R E T \sigma_{C}^{2}$ & $\mathrm{Q}_{8}$ \\
\hline Testemunhas (T) & $\mathrm{T}-1$ & $Q_{7}$ & $\sigma^{2}+R E \sigma_{C t}^{2}+R E C V_{t}$ & $\mathrm{Q}_{7}^{\prime}$ \\
\hline C $\mathrm{X} T$ & $(C-1)(T-1)$ & $Q_{6}$ & $\sigma^{2}+R E \sigma_{c t}^{2}$ & $Q_{5}$ \\
\hline$E \times T$ & $(E-1)(T-1)$ & & $\sigma^{2}+R \sigma_{e c t}^{2}+V_{e t}$ & \\
\hline$E \times C$ & $(E-I)(C-I)$ & $Q_{4}$ & $\sigma^{2}+R T \sigma_{e C}^{2}$ & $Q_{4}$ \\
\hline$E \times C \times T$ & $(E-I)(C-I)(T-I)$ & $\mathrm{Q}_{3}$ & $\sigma^{2}+C{ }^{\prime} \sigma_{\text {ect }}^{2}$ & $Q_{3} / Q_{1}$ \\
\hline $\mathrm{B} 10 \mathrm{CO} / \mathrm{E}$ & $(\mathrm{R}-\mathrm{l}) \mathrm{E}$ & $\mathrm{Q}_{2}$ & $\sigma^{2}+C \Gamma \sigma_{b: e}^{2}$ & $Q_{2} / Q_{1}$ \\
\hline Residuo mëdio & $(T C-1)(R-1) E$ & $Q_{1}$ & $\sigma^{2}$ & \\
\hline TOTAL & $\operatorname{TREC}-1$ & & & \\
\hline
\end{tabular}


Tabela 4. Esquema de análise de variância individual para caracteres que não apresentaram interações significa tivas envolvendo o efeito de conjuntos com as espe ranças matemáticas dos quadrados mëdios.

\begin{tabular}{|c|c|c|c|c|}
\hline $\begin{array}{l}\text { Fontes de } \\
\text { variação }\end{array}$ & GL & $Q M$ & $E(Q M)$ & $F$ \\
\hline Genótipos & $G-1$ & $Q_{3}$ & $\sigma^{2}+R V g$ & $Q_{3} /$ \\
\hline Repetições & $\mathrm{R}-\mathrm{l}$ & $Q_{2}$ & $\sigma^{2}+G \sigma_{x}^{2}$ & $Q_{2} / O$ \\
\hline Resíduo & $(G-I)(R-I)$ & $Q_{1}$ & $\sigma^{2}$ & \\
\hline TOTAL & $\mathrm{RG}-1$ & & & \\
\hline
\end{tabular}


Tabela 5. Esquema de anälise de variância conjunta para carac teres que não apresentaram interações significativas envolvendo o efeito de conjuntos, com as esperanças matemáticas dos quadrados médios.

Fontes de

variação

GL

QM

$E(g M)$

F

Epocas (E)

E-1

$Q_{5} \quad \sigma^{2}+G \sigma_{r: e^{2}}^{2} \mathrm{RGV}$

$Q_{5} / Q_{2}$

Genōtipos (G)

G-1.

$\mathrm{Q}_{4} \quad \sigma^{2}+\mathrm{REVg}$

$Q_{4} / Q_{1}$

$E \times G$

$(\mathrm{E}-1)(\mathrm{G}-1)$

$Q_{3}$

$\sigma^{2}+\operatorname{Veg}$

$Q_{3} / Q_{1}$

Repetiçöes/E

$(\mathrm{R}-\mathrm{l}) \mathrm{E} \quad \mathrm{Q}_{2}$

$\sigma^{2}+G \sigma_{r: e}^{2}$

$Q_{2} / Q_{1}$

Resĩulo médio

$(G-I)(R-I) E \quad Q_{1}$

$\sigma^{2}$

TOTAL

EGR-1 
63.

Tabela 6. Esquema de análise de variância individual para caracteres que apresentaram interações significativas envolvendo o efeito de conjuntos, com as esperanças matemáticas dos quadrados mëdios.

\begin{tabular}{|c|c|c|c|c|}
\hline $\begin{array}{l}\text { Fontes de } \\
\text { variação }\end{array}$ & GL & $Q M$ & $E(Q M)$ & $\mathrm{F}$ \\
\hline Conjuntos (C) & $\mathrm{C}-1$ & $\mathrm{Q}_{4}$ & $\sigma^{2}+R G \sigma_{C}^{2}$ & $Q_{4} / Q_{1}$ \\
\hline Genótipos/C & $(G-1) C$ & $Q_{3}$ & $\sigma^{2}+R \sigma_{g: c}^{2}$ & $Q_{3} / Q_{1}$ \\
\hline Repetições & $\mathrm{R}-1$ & $\mathrm{Q}_{2}$ & $\sigma^{2}+C G \sigma_{r}^{2}$ & $Q_{2} / Q_{1}$ \\
\hline Resíduo & $(C G-1)(R-1)$ & $\mathrm{Q}_{1}$ & $o^{2}$ & \\
\hline TOTAL & $R G-I$ & & & \\
\hline
\end{tabular}


Tabela 7. Esquema de análise de variância conjunta para os caracteres que apresentaram interações significativas envolvendo o efeito de conjuntos, com as esperanças matemäticas dos quadrados mëdios.

\begin{tabular}{|c|c|c|c|c|}
\hline $\begin{array}{l}\text { Fontes de } \\
\text { variação }\end{array}$ & GL & $Q M$ & $E(Q M)$ & $F$ \\
\hline Epocas (E) & $(E-1)$ & $Q_{7}$ & $\sigma^{2}+C G \sigma_{r: e^{2}}^{+R G}{ }_{e c}^{2}+R C G V$ & $\frac{Q_{7+Q_{1}}}{Q_{2}+Q_{4}}$ \\
\hline Conjuntos (C) & $(C-1)$ & & $\sigma^{2}+E R G \sigma_{C}^{2}$ & $Q_{6} / Q_{I}$ \\
\hline Genötipos (G)/C & $(G-1) C$ & $Q_{5}$ & $\sigma^{2}+\operatorname{ER} V_{g: c}$ & $Q_{5}$ \\
\hline$E \times C$ & $(E-1)(C-1)$ & $Q_{4}$ & $\sigma^{2}+R G \sigma_{e c}^{2}$ & $Q_{4} / Q_{1}$ \\
\hline $\mathrm{E} \times \mathrm{G} / \mathrm{C}$ & $(E-1)(G-1) C$ & & $\sigma^{2}+V_{e g: c}$ & $Q_{3} / Q_{1}$ \\
\hline Repetições/E & $(R-1) E$ & $\dot{Q}_{2}$ & $\sigma^{2}+G C \sigma_{r: e}^{2}$ & ${ }^{Q_{2}} / Q_{1}$ \\
\hline Resĩduo médio & $(G-1)(R-I) E$ & $Q_{1}$ & $\sigma^{2}$ & \\
\hline TOIAS & GRE-1 & & & \\
\hline
\end{tabular}


65.

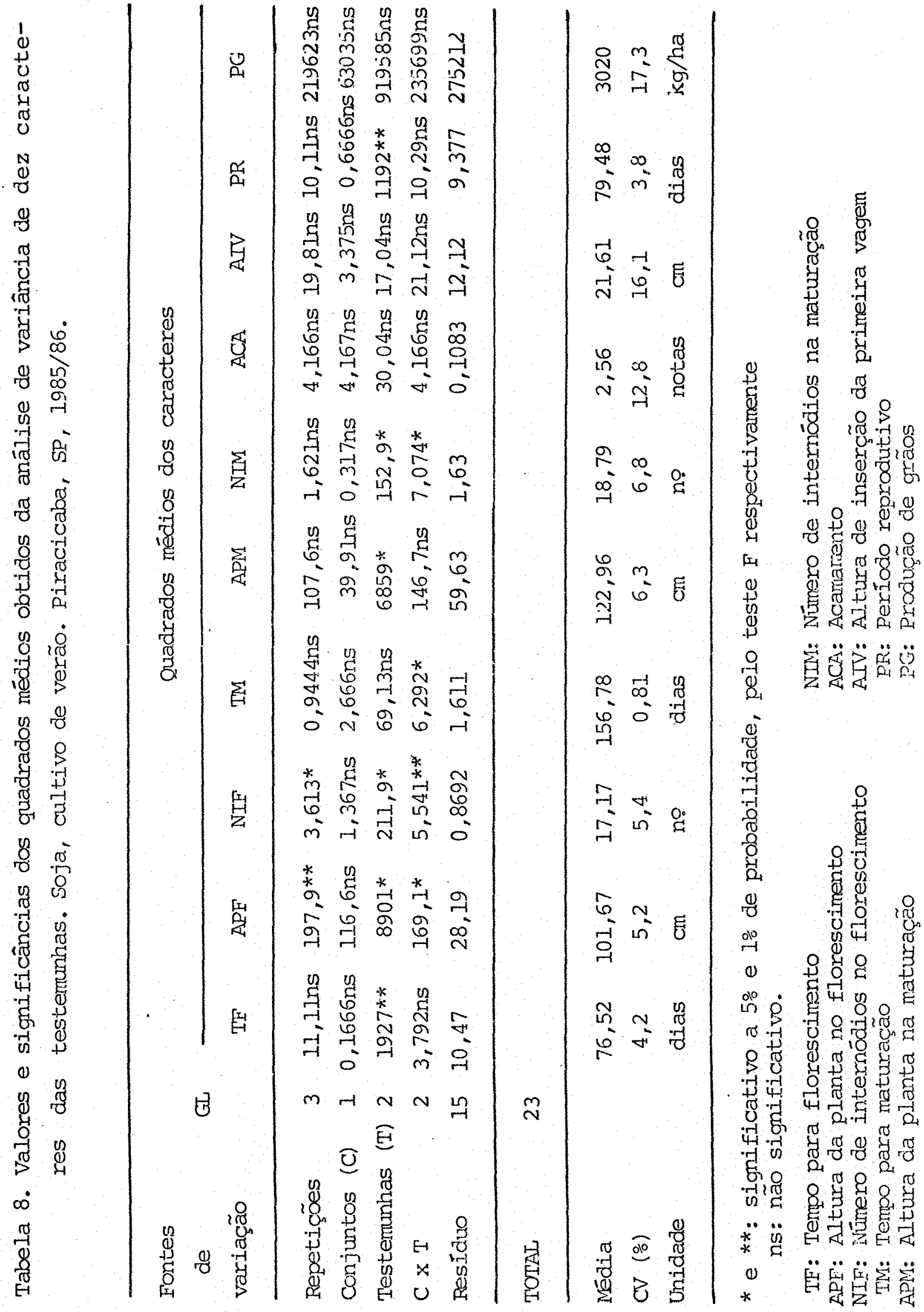


66.

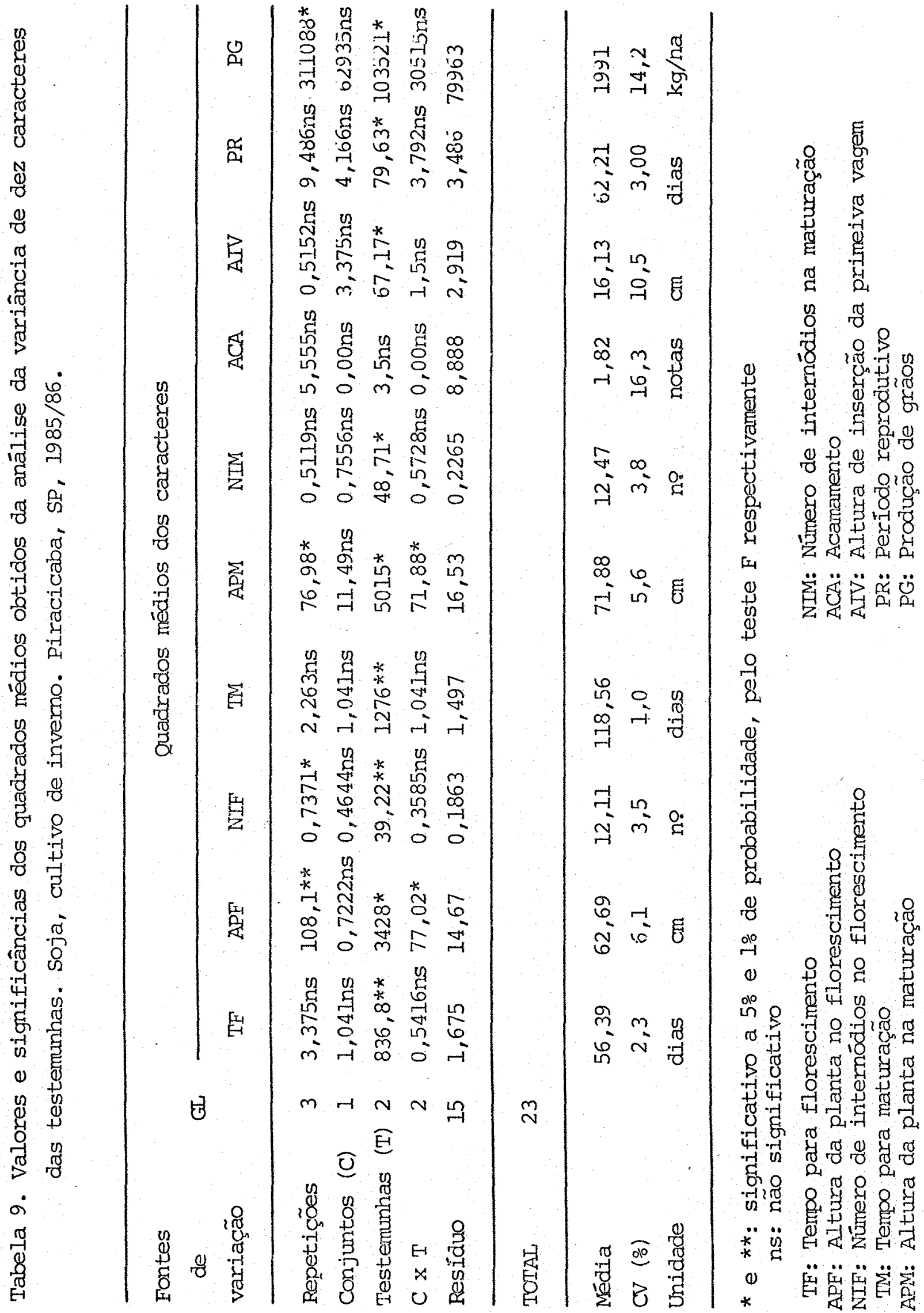




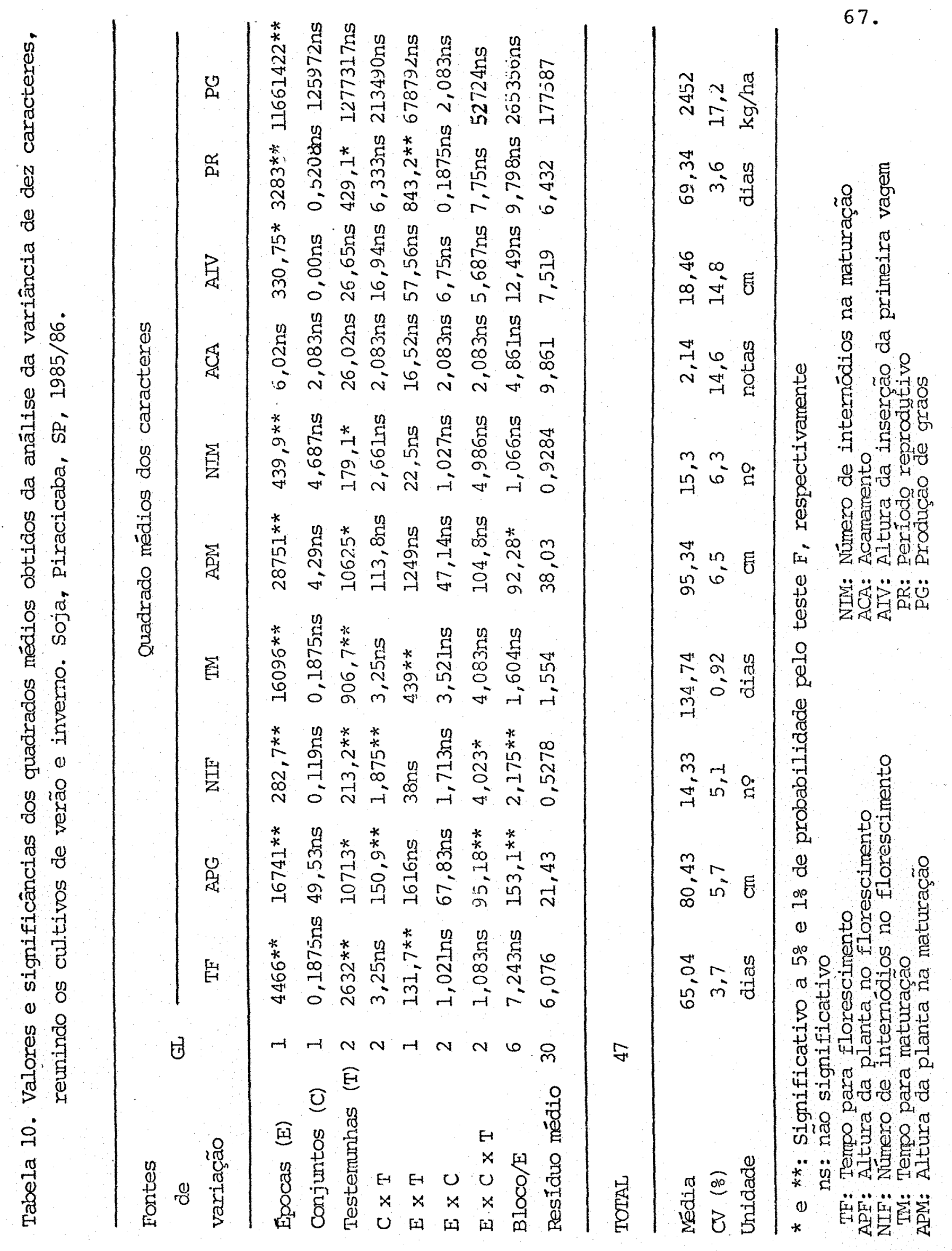


68.

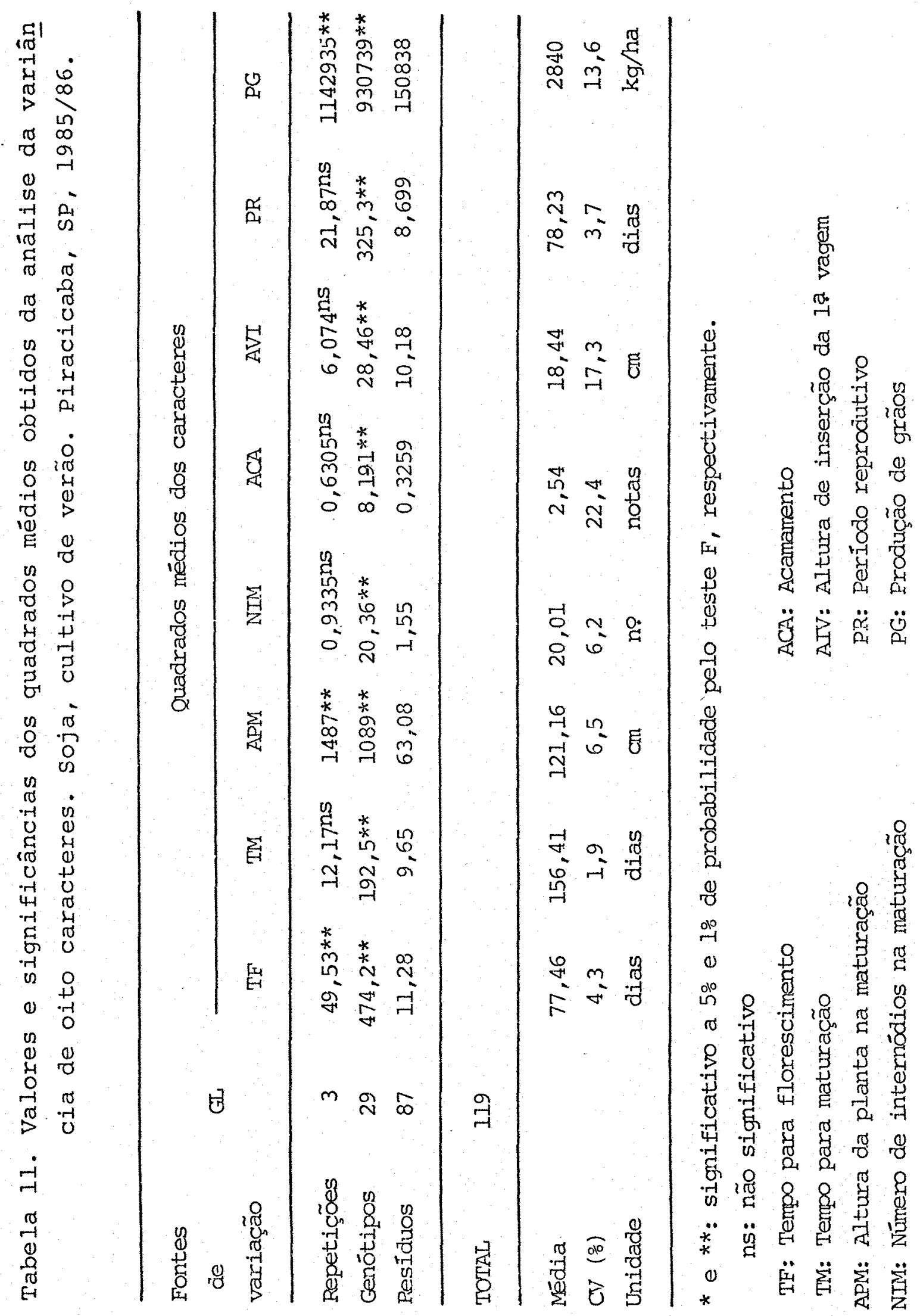




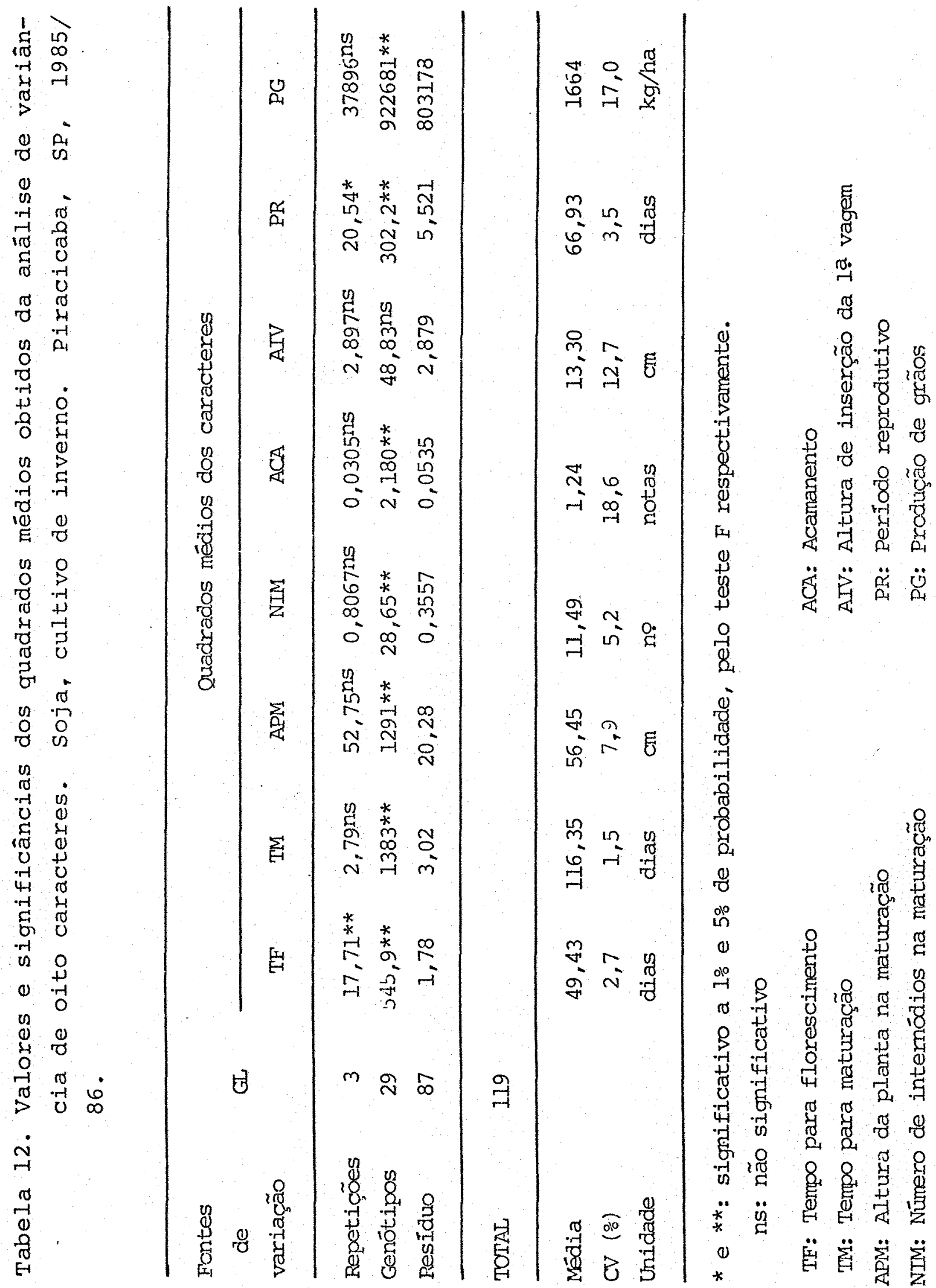


70.

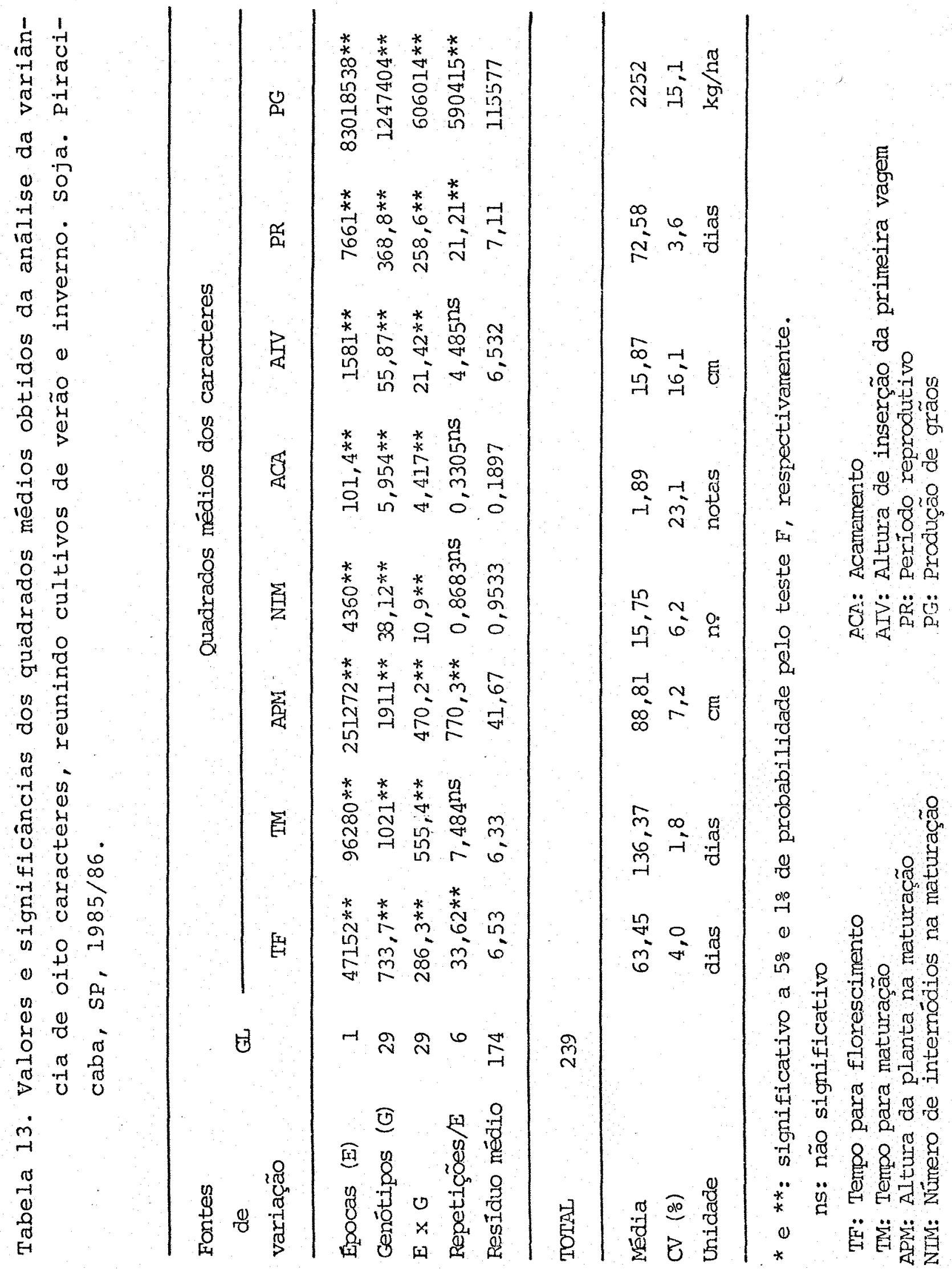


Tabela 14. Valores e significâncias dos quadrados médios obti dos da análise da variância dos caracteres, altura da planta no florescimento (APF) e número de inter nódios no florescimento (NIF) nas duas épocas de cultivo. Soja. Piracicaba, SP, 1985/86.

\begin{tabular}{|c|c|c|c|c|c|}
\hline \multirow{3}{*}{$\begin{array}{l}\text { Fontes de } \\
\text { variação }\end{array}$} & \multirow{3}{*}{ GL } & \multicolumn{4}{|c|}{ Quadrados médios dos caracteres } \\
\hline & & \multicolumn{2}{|c|}{$\mathrm{APE}$} & \multicolumn{2}{|c|}{ NIF } \\
\hline & & Verão & Inverno & Verão & Inverno \\
\hline Repetições & 3 & $1903 * *$ & $34,97 \mathrm{~ns}$ & $4,33^{*}$ & $0,5922^{n s}$ \\
\hline Conjuntos (C) & 1 & $2274 * *$ & $80,76 * *$ & $3,12^{\mathrm{ns}}$ & $15,00 * *$ \\
\hline Genötipos/C & 28 & $209 * *$ & $934,9 * *$ & $36,76 * *$ & $27,6 * *$ \\
\hline Resícuos & 87 & 75,84 & 16,65 & 1,096 & 0,2965 \\
\hline TOTAL & 119 & & & & \\
\hline Média & & 102,44 & 49,49 & 18,54 & 11,25 \\
\hline $\mathrm{CV}\left(\frac{0}{6}\right)$ & & 8,5 & 8,2 & 5,6 & 4,8 \\
\hline Unidade & & $\mathrm{cm}$ & $\mathrm{cm}$ & no & ne \\
\hline
\end{tabular}

* e**: significativo a 5\% e 1\% de probabilidade, pelo teste F respectivamente

ns: não significativo. 
Tabela 15. Valores e significâncias dos quadrados médios da anālise da variância dos caracteres, altura da plan ta no florescimento $(A P F)$ e nümero de internódios no florescimento (NIF), reunindo os cultivos de ve rão e inverno. Soja. Piracicaba, SP, 1985/86.

\begin{tabular}{|c|c|c|c|}
\hline \multirow{2}{*}{$\begin{array}{l}\text { Fontes de } \\
\text { variação }\end{array}$} & \multirow{2}{*}{ GI } & \multicolumn{2}{|c|}{ Quadrados médios dos caracteres } \\
\hline & & APF & NIF \\
\hline Epocas (E) & 1 & $132247^{\mathrm{ns}}$ & $2649^{\text {ns }}$ \\
\hline Conjuntos (C) & 1 & 1,602 & $19,24 * *$ \\
\hline Genōtipos (G)/C & 28 & $1105 * *$ & $21,81 * *$ \\
\hline$E \times C$ & 1 & $4378 * *$ & $47,45 * *$ \\
\hline$E \times G / C$ & 28 & $2967 * *$ & $57,71 * *$ \\
\hline Repetições/E & 6 & $976,1 * *$ & $2,672 * *$ \\
\hline Residuo mëdio & 174 & 47,06 & 0,7678 \\
\hline TOTAL & 239 & & \\
\hline Média & & 78,44 & 15,13 \\
\hline $\mathrm{CV}\left(\frac{\circ}{0}\right)$ & & 8,7 & 5,8 \\
\hline Unidade & & $\mathrm{cm}$ & no \\
\hline
\end{tabular}

* e **: significativo a 5\% e 1\% de probabilidade, pelo teste F respectivamente.

ns: não significativo 
Tabela 16. Tempo para florescimento de 30 genótipos de soja em cultivos de verão e inverno. Estratificação em dois conjuntos experimentais com três testemunhas comuns. Médias de quatro repetições. Piracicaba, $1985 / 86$.

\begin{tabular}{|c|c|c|c|c|c|}
\hline \multirow{2}{*}{ Genōtipos } & \multicolumn{2}{|c|}{ Conjunto 1} & \multirow{2}{*}{ Genötipos } & \multicolumn{2}{|c|}{ Conjunto 2} \\
\hline & verão & Inverno & & Verão & Inverno \\
\hline & - no de & dias -- & & $--n: d$ & e dias -- \\
\hline UFV-Araguaia & 81 & 39 & Numbaira & 80 & 51 \\
\hline $\mathrm{IAC}-6$ & 88 & 52 & Go 70.1084 & 76 & 43 \\
\hline $\mathrm{Bi} 10 \times \mathrm{x}$ & 61 & 39 & Paranagoiana & 64 & 72 \\
\hline OC 8362 & 66 & 57 & Tropical & 88 & 66 \\
\hline$B R-80-14887$ & 59 & 33 & Doko & 84 & 52 \\
\hline Cristalina & 82 & 47 & Jūpite & 91 & 49 \\
\hline $\mathrm{IAC}-12$ & 62 & 44 & IAC -5 & 66 & 44 \\
\hline$B R-9$ & 78 & 50 & Santa Maria & 73 & 37 \\
\hline$I A C-11$ & 75 & 45 & $I A C-8$ & 63 & 52 \\
\hline$B R-11$ & 96 & 73 & EMGOPA 301 & 86 & 43 \\
\hline UFV-3 & 74 & 36 & GO $79-1039$ & 89 & 45 \\
\hline Timbira & 93 & 66 & $U F V-2$ & 68 & 35 \\
\hline$U F V-4$ & 61 & 38 & $U E V-1$ & 79 & 39 \\
\hline$I A C-9$ & 84 & 49 & UEV-5 & 86 & 43 \\
\hline BR $79-63$ & 82 & 71 & $B R-10$ & 88 & 67 \\
\hline$I A C-8$ & 68 & 52 & IAC- 8 & 68 & 52 \\
\hline$I A C-12$ & 60 & 45 & $I A C-12$ & 60 & 45 \\
\hline Tropical & 91 & 65 & Tropical & 91 & 65 \\
\hline
\end{tabular}


Tabela 17. Periodo reprodutivo de 30 genótipos de soja em cuI tivos de verão e inverno. Estratificação em dois conjuntos experimentais com três testemunhas comuns. Médias de quatro repetições. Piracicaba,1985/ 86 .

\begin{tabular}{|c|c|c|c|c|c|}
\hline \multirow{2}{*}{ Genōtipos } & \multicolumn{2}{|c|}{ Conjunto 1} & \multirow{2}{*}{ Genōtipos } & \multicolumn{2}{|c|}{ Conjunto 2} \\
\hline & Verão & Inverno & & Verão & Inverno \\
\hline & -- no de & dias -- & & -- no de & e dias -- \\
\hline UFV-Araguaia & 79 & 62 & Numbaíra & 74 & 69 \\
\hline IAC -6 & 65 & 61 & Go 70.1084 & 83 & 70 \\
\hline Biloxi & 79 & 57 & Paranagoiana & 97 & 91 \\
\hline OC 8362 & 76 & 69 & Tropical & 63 & 62 \\
\hline$B R-80-14887$ & 90 & 63 & Doko & 77 & 66 \\
\hline Cristalina & 82 & 74 & Jüpiter & 67 & 62 \\
\hline$I A C-12$ & 88 & 58 & IAC -5 & 81 & 57 \\
\hline$B R-9$ & 75 & 68 & Santa Maria & 77 & 59 \\
\hline$I A C-11$ & 80 & 72 & IAC -8 & 84 & 60 \\
\hline$B R-11$ & 70 & 64 & EMGOPA 301 & 72 & 66 \\
\hline$U F V-3$ & 78 & 64 & GO $79-1039$ & 70 & 62 \\
\hline Timbira & 68 & 60 & $U F V-2$ & 92 & 64 \\
\hline$U F V-4$ & 101 & 61 & $U F V-1$ & 82 & 63 \\
\hline IAC -9 & 75 & 71 & UFV-5 & 81 & 70 \\
\hline BR $79-63$ & 82 & 76 & $B R-10$ & 76 & 70 \\
\hline$I A C-8$ & 81 & 63 & $I A C-8$ & 81 & 63 \\
\hline$I A C-12$ & 90 & 56 & $I A C-12$ & 90 & 56 \\
\hline Tropical & 62 & 61 & Tropical & 62 & 61 \\
\hline
\end{tabular}


Tabela 18. Tempo para maturação de 30 genótipos de soja em cul tivos de verão e inverno. Estratificação em dois conjuntos experimentais com três testemunhas comuns. Médias de quatro repetições. Piracicaba, 1985/ 86.

\begin{tabular}{|c|c|c|c|c|c|}
\hline \multirow{2}{*}{ Genōtipos } & \multicolumn{2}{|c|}{ Conjunto 1} & \multirow{2}{*}{ Genōtipos } & \multicolumn{2}{|c|}{ Conjunto 2} \\
\hline & Verão & Inverno & & Verão & Inverno \\
\hline & -n no de & dias -- & & - no d & dias -- \\
\hline UFV-Araguaia & 160 & 101 & Numbaira & 154 & 120 \\
\hline IAC -6 & 153 & 113 & Go 70.1084 & 159 & 113 \\
\hline Biloxi & 140 & 96 & Paranagoiana & 161 & 163 \\
\hline OC 8362 & 142 & 126 & Tropical & 151 & 128 \\
\hline$B R-80-14887$ & 149 & 96 & Doko & 161 & 118 \\
\hline Cristalina & 164 & 121 & Jüpiter & 158 & 111 \\
\hline$I A C-12$ & 150 & 102 & $I A C-5$ & 147 & 101 \\
\hline$B R-9$ & 153 & 118 & Santa Maria & 150 & 96 \\
\hline$I A C-11$ & 155 & 117 & $I A C-8$ & 147 & 112 \\
\hline $\mathrm{BR}-11$ & 166 & 137 & EMGOPA 301 & 158 & 109 \\
\hline$U F V-3$ & 152 & 100 & GO $79-1039$ & .159 & 107 \\
\hline Timbira & 161 & 126 & $U F V-2$ & 160 & 99 \\
\hline$U F V-4$ & 162 & 99 & $U E V-1$ & 161 & 102 \\
\hline IAC -9 & 159 & 120 & $U F V-5$ & 167 & 113 \\
\hline BR 79-63 & 164 & 157 & $B R-10$ & 164 & 137 \\
\hline IAC- 8 & 149 & 115 & IAC -8 & 149 & 115 \\
\hline$I A C-12$ & 150 & 101 & $I A C-12$ & 150 & 101 \\
\hline Tropical & 153 & 126 & Tropical & 153 & 126 \\
\hline
\end{tabular}


Tabela 19. Altura da planta no florescimento de 30 genótipos de soja em cultivos de verão e inverno. Estratifi cação em dois conjuntos experimentais com três tes temunhas comuns. Médias de quatro repetições. Pira cicaba, $1985 / 86$.

\begin{tabular}{|c|c|c|c|c|c|}
\hline \multirow{2}{*}{ Genötipos } & \multicolumn{2}{|c|}{ Conjunto 1} & \multirow{2}{*}{ Genōtipos } & \multicolumn{2}{|c|}{ Conjunto 2} \\
\hline & Verão & Inverno & & Verão & Inverno \\
\hline & $----\mathrm{cm}$ & $-\cdots--$ & & $---c \mathrm{~cm}$ & $-\cdots$ \\
\hline UFV-Araguaia & 95 & 32 & Numbaíra & 104 & $49^{\prime \prime}$ \\
\hline IAC- 6 & 133 & 57 & Go 70.1084 & 94 & 46 \\
\hline Biloxi & 59 & 42 & Paranagoiana & 82 & 62 \\
\hline OC 8362 & 36 & 52 & Tropical & 130 & 75 \\
\hline$B R-80-14887$ & 59 & 26 & Doko & 123 & 48 \\
\hline Cristalina & 107 & 51 & Jūpiter & 130 & 61 \\
\hline$I A C-12$ & 61 & 39 & $I A C-5$ & 88 & 47 \\
\hline$B R-9$ & 104 & 55 & Santa Maria & 83 & 34 \\
\hline$I A C-11$ & 100 & 45 & $I A C-8$ & 97 & 69 \\
\hline$B R-11$ & 129 & 94 & EMGOPA 301 & 121 & 47 \\
\hline$U F V-3$ & 93 & 34 & GO $79-1039$ & 111 & 45 \\
\hline Timbira & 138 & 53 & UFV-2 & 99 & 33 \\
\hline$U F V-4$ & 65 & 37 & $U F V-1$ & 102 & 29 \\
\hline IAC -9 & 121 & 40 & $U F V-5$ & 98 & 35 \\
\hline $\mathrm{BR} 79-63$ & 109 & 63 & $B R-10$ & 125 & 70 \\
\hline$I A C-8$ & 79 & 63 & $I A C-8$ & $90^{\circ}$ & 69 \\
\hline IAC- 12 & 75 & 37 & $I A C-12$ & 69 & 36 \\
\hline Tropical & 131 & 80 & Tropical & 139 & 74 \\
\hline
\end{tabular}


Tabela 20. Número de internódios no florescimento de 30 genótipos de soja em cultivos de verão e inverno. Estratificação em dois conjuntos experimentais com três testemunhas comuns. Médias de quatro repetições. Piracicaba, 1985/86.

\begin{tabular}{|c|c|c|c|c|c|}
\hline \multirow{2}{*}{ Genótipos } & \multicolumn{2}{|c|}{ Conjunto 1} & \multirow{2}{*}{ Genōtipos } & \multicolumn{2}{|c|}{ Conjunto 2} \\
\hline & Verão & Inverno & & Verão & Inverno \\
\hline & ---119 & $-\cdots$ & & $---n$ n! & ---- \\
\hline UFV-Araguaia & 19 & 09 & Numbaíra & 18 & 11 \\
\hline$I A C-6$ & 21 & 11 & Go 70.1084 & 16 & 09 \\
\hline Biloxi & 12 & 11 & Paranagoiana & 17 & 15 \\
\hline oc 3362 & 16 & 12 & Tropical & 21 & 14 \\
\hline$B R-80-14887$ & 13 & 07 & Doko & 21 & 11 \\
\hline Cristalina & 21 & 12 & Júpiter & 20 & 10 \\
\hline$I A C-12$ & 14 & 10 & $I A C-5$ & 17 & 10 \\
\hline$B E-9$ & 21 & 11 & Santa Maria & 18 & 09 \\
\hline$I A C-11$ & 20 & 11 & $I A C-8$ & 14 & 11 \\
\hline$B R-I I$ & 23 & 19 & EMGOPA 301 & 20 & 10 \\
\hline$U F V-3$ & 17 & 08 & Go $79-1039$ & 20 & 10 \\
\hline Timbira & 22 & 14 & $\mathrm{UFV}-2$ & 17 & 08 \\
\hline$U F V-4$ & 15 & 10 & UFV-1 & 18 & 03 \\
\hline IAC -9 & 20 & 10 & UFV-5 & 22 & 10 \\
\hline $\mathrm{BR} 79-63$ & 21 & 16 & $B R-10$ & 21 & 15 \\
\hline IAC -8 & 14 & 11 & $I A C-8$ & 15 & 11 \\
\hline$I A C-12$ & 14 & 09 & $I A C-12$ & 12 & 09 \\
\hline Tropical & 22 & 14 & Tropical & 23 & 14 \\
\hline
\end{tabular}


Tabela 21. Acamamento de 30 genótipos de soja em cultivos de verão e inverno. Estratificação em dois conjuntos experimentiais com três testemunhas comuns. llédias de ciuatro repetições. Piracicaba, 1985/86.

\begin{tabular}{|c|c|c|c|c|c|}
\hline \multirow{2}{*}{ Genōtipos } & \multicolumn{2}{|c|}{ Conjunto 1} & \multirow{2}{*}{ Genōtipos } & \multicolumn{2}{|c|}{ Conjunto 2} \\
\hline & Verão & Inverno & & verão & Inverno \\
\hline & $-\quad$ nota & as $1 /$ & & -n nota & $s .1 /$ \\
\hline UFV-Araguaia & 1,0 & 1,0 & Numbaíra & 5,0 & 1,0 \\
\hline IAC- 6 & 4,0 & 1,0 & Go 70.1084 & 1.0 & 1,0 \\
\hline Biloxi & 3,0 & 1,0 & Paranagoiana & 1,0 & 1,0 \\
\hline OC 8362 & 1,0 & 1,0 & Tropical & 4,0 & 1,0 \\
\hline$B R-80-14887$ & 1,0 & 1,0 & Doko & 4,0 & 1,0 \\
\hline Cristalina & 2,0 & 1,0 & Jüpiter & 4,0 & 1,0 \\
\hline$I A C-12$ & 1,0 & 1,0 & IAC -5 & 4,0 & 1,0 \\
\hline$B R-9$ & 1,0 & 1,0 & Santa Maria & 4,0 & 1,0 \\
\hline$I A C-11$ & 2,0 & 1,0 & IAC- 8 & 1,0 & 1,0 \\
\hline $\mathrm{BR}-11$ & 4,0 & 2,0 & EMGOPA 301 & 3,0 & 1,0 \\
\hline $\mathrm{UFV}-3$ & 1,0 & 1,0 & Go $79-1039$ & 2,0 & 1,0 \\
\hline Timbira & 5,0 & 1,0 & $U F V-2$ & 1,0 & 1,0 \\
\hline$U F V-4$ & 2,0 & 1,0 & $U E V-1$ & 2,0 & 1,0 \\
\hline IAC-9 & 4,0 & 1,0 & $U F V-5$ & 1,0 & 1,0 \\
\hline BR $79-63$ & 2,0 & 1,0 & $B R-10$ & 4,0 & 5,0 \\
\hline$I A C-8$ & 1,0 & 2,0 & IAC- 8 & 1,0 & 2,0 \\
\hline$I A C-12$ & 1,0 & 1,0 & $I A C-12$ & 1,0 & 1,0 \\
\hline Tropical & 5,0 & 2,0 & Tropical & 5,0 & 2,0 \\
\hline
\end{tabular}

I/ Nota 1 (todas plantas eretas na parcela) a nota 5 (todas plantas prostadas na parcela). 
Tabela 22. Altura de inserção da primeira vagem de 30 genótipos de soja em cultivos de verão e inverno. Estratificação em dois conjuntos experimentais com três testemunhas comuns. Méãias de quatro repetições. Pi racicaba, $1985 / 36$.

\begin{tabular}{|c|c|c|c|c|c|}
\hline \multirow{2}{*}{ Genötipos } & \multicolumn{2}{|c|}{ Conjunto 1} & \multirow{2}{*}{ Genótipos } & \multicolumn{2}{|c|}{ Conjunto 2} \\
\hline & verão & Inverno & & Verão & Inverno \\
\hline & $---\cdots c m$ & $-\cdots-\cdots$ & & $---\mathrm{cm}$ & ----- \\
\hline UFV-Araguaia & 17 & 11 & Numbaira & 22 & 12 \\
\hline IAC -6 & 22 & 16 & Go 70.1084 & 20 & 12 \\
\hline Biloxi & 13 & 10 & Paranagoiana & 20 & 22 \\
\hline OC 8362 & 22 & 20 & Tropical & 22 & 21 \\
\hline$B R-80-14887$ & 16 & 10 & Doko & 21 & 16 \\
\hline Cristalina & 16 & 13 & Jüpiter & 21 & 14 \\
\hline IAC -12 & 18 & 11 & $I A C-5$ & 21 & 11 \\
\hline$B S-9$ & 20 & 13 & Santa Maria & 16 & 9 \\
\hline$I A C-11$ & 17 & 13 & $I A C-8$ & 23 & 16 \\
\hline$B R-11$ & 16 & 20 & EMGOPA 301 & 15 & 13 \\
\hline$U F V-3$ & 17 & 12 & GO $79-1039$ & 17 & 11 \\
\hline Timbira & 19 & 14 & $U F V-2$ & 17 & 10 \\
\hline$U F V-4$ & 21 & 10 & $U F V-1$ & 16 & 12 \\
\hline IAC -9 & 16 & 10 & $U F V-5$ & 17 & 9 \\
\hline BR $79-63$ & 16 & 16 & $B R-10$ & 17 & 16 \\
\hline$-\infty---\infty-\infty-\infty-\infty$ & $-\infty-$ & ------ & $----\infty--$ & $--\infty$ & $---\infty$ \\
\hline IAC -8 & 18 & 17 & $I A C-8$ & 20 & 16 \\
\hline$I A C-12$ & 21 & 13 & $I A C-12$ & 23 & 13 \\
\hline Tropical & 22 & 19 & Tropical & 20 & 17 \\
\hline
\end{tabular}


Tabela 23. Altura da planta na maturação de 30 genōtipos de soja em cultivos de verão e inverno. Estratificação em dois conjuntos experimentais com três teste munhas comuns. Médias de quatro repetições. Piracicaba, 1985/86.

\begin{tabular}{|c|c|c|c|c|c|}
\hline \multirow{2}{*}{ Genōtipos } & \multicolumn{2}{|c|}{ Conjunto 1} & \multirow{2}{*}{ Genōtipos } & \multicolumn{2}{|c|}{ Conjunto 2} \\
\hline & Verão & Inverno & & Verão & Inverno \\
\hline & $-\cdots c$ & $n----$ & & $\ldots-\mathrm{cm}$ & $-\cdots--$ \\
\hline UFV-Araguaia & 111 & 36 & Numbaira & 111 & 55 \\
\hline$I A C-6$ & 150 & 64 & Go 70.1084 & 103 & 52 \\
\hline Biloxi & 102 & 48 & Paranagoiana & 119 & 84 \\
\hline OC 3362 & 114 & 73 & Tropical & 148 & 87 \\
\hline$B R-80-14887$ & 91 & 32 & Doko & 131 & 55 \\
\hline Cristalira & 121 & 57 & Jüpiter & 136 & 69 \\
\hline$I A C-12$ & 91 & 44 & $I A C-5$ & 126 & 51 \\
\hline $3 R-9$ & 124 & 60 & Santa Maria & 38 & 36 \\
\hline$I A C-11$ & 126 & 51 & $I A C-8$ & 121 & 75 \\
\hline$B R-11$ & 138 & 101 & EMGOPA 301 & 135 & 50 \\
\hline$U F V-3$ & 109 & 42 & Go $79-1039$ & 129 & 48 \\
\hline Timbira & 144 & 66 & $U F V-2$ & 116 & 37 \\
\hline$U E V-4$ & 131 & 40 & $U F V-1$ & 110 & 34 \\
\hline$I A C-9$ & 129 & 45 & $U F V-5$ & 109 & 38 \\
\hline BR $79-63$ & 129 & 78 & $B R-10$ & 141 & 84 \\
\hline$I A C-8$ & 100 & 72 & IAC -8 & 107 & 77 \\
\hline$I A C-12$ & 102 & 43 & $I A C-12$ & 95 & 40 \\
\hline Tropical & 147 & 94 & Tropical & 155 & 87 \\
\hline
\end{tabular}


Tabela 24. Número de internódios na maturação de 30 genótipos de soja em cultivos de verão e inverno. Estratificação em dois conjuntos experimentais com três tes temunhas comuns. Médias de quatro repetições. Piracicaba, $1985 / 86$.

\begin{tabular}{|c|c|c|c|c|c|}
\hline \multirow{2}{*}{ Genótipos } & \multicolumn{2}{|c|}{ Conjunto 1} & \multirow{2}{*}{ Genōtipos } & \multicolumn{2}{|c|}{ Conjunto 2} \\
\hline & Verão & Inverno & & Verão & Inverno \\
\hline & $-\infty \cdots n$ & $--\cdots$ & & $---n !$ & $-m \div--$ \\
\hline UFV-Araguaia & 20 & 09 & Numbaira & 18 & 11 \\
\hline IAC -6 & 21 & 11 & Go 70.1084 & 16 & 09 \\
\hline $\mathrm{Bi} 10 \mathrm{xi}$ & 21 & 11 & Paranagoiana & 19 & 15 \\
\hline OC 8362 & 17 & 13 & Tropical & 21 & 14 \\
\hline$B R-80-14887$ & 15 & 07 & Doko & 21 & 11 \\
\hline Cristalina & 21 & 12 & Jüpiter & 20 & 10 \\
\hline $\operatorname{IAC}-12$ & 16 & 10 & IAC -5 & 20 & 10 \\
\hline $\mathrm{BR}-9$ & 21 & 11 & Santa Maria & 18 & 09 \\
\hline$I A C-11$ & 20 & 11 & IAC- 8 & 17 & 11 \\
\hline$B R-11$ & 23 & 19 & EMGOPA 301 & 20 & 10 \\
\hline UEV-3 & 17 & 08 & GO $79-1039$ & 20 & 10 \\
\hline Timbira & 22 & 14 & $\mathrm{UEV}-2$ & 17 & 08 \\
\hline$U F V-4$ & 22 & 10 & $U F V-1$ & 18 & 08 \\
\hline$I A C-9$ & 20 & 10 & $U F V-5$ & 22 & 10 \\
\hline BR $79-63$ & 21 & 16 & $B R-10$ & 21 & 15 \\
\hline--------- & ---- & $---\infty-\infty$ & $-\cdots-\cdots$ & -- & $-\cdots-\cdots$ \\
\hline IAC- 8 & 14 & 11 & $I A C-8$ & 15 & 11 \\
\hline$I A C-12$ & 16 & 09 & $I A C-12$ & 15 & 09 \\
\hline Tropical & 22 & 14 & Tropical & 23 & 14 \\
\hline
\end{tabular}


Tabela 25. Produção de grãos (ordem de classificação relativa) de 30 genótipos de soja em cultivos de verão e inverno. Estratificação em dois conjuntos experimen tais com três testemunhas comuns. Médias de quatro repetições. Piracicaba, 1985/86.

\begin{tabular}{|c|c|c|c|c|c|}
\hline \multirow{2}{*}{ Genōtipos } & \multicolumn{2}{|c|}{ Conjunto 1} & \multicolumn{3}{|c|}{ Conjunto 2} \\
\hline & Verão & Inverno & & Verão & Inverno \\
\hline & \multicolumn{2}{|c|}{ - kg/ha - - } & \multirow[b]{2}{*}{ Numbaĩra } & $-\infty \mathrm{kc}$ & ha -- - \\
\hline UFV-Araguaia & $3641(2)$ & $1596(17)$ & & $3180(7)$ & $1892(10)$ \\
\hline IAC-6 & $2480(25)$ & $2156(7)$ & Go 79.1084 & $3059(9)$ & $1760(15)$ \\
\hline Biloxi & $1664(30)$ & $1297(24)$ & Paranagoiana & $3013(10)$ & $2442(2)$ \\
\hline$\propto 8362$ & $2917(12)$ & $1753(16)$ & Tropical & $2638(20)$ & $2160(6)$ \\
\hline$B R-80-14887$ & $2254(28)$ & $710(30)$ & Doko & $2544(22)$ & $2200(4)$ \\
\hline Cristalina & $3873(1)$ & $2081(8)$ & Jüpiter & $2280(27)$ & $1817(11)$ \\
\hline $\mathrm{IAC}-12$ & $3131(8)$ & $1798(13)$ & $I A C-5$ & $2503(23)$ & $825(29)$ \\
\hline $\mathrm{BR}-9$ & $3631(3)$ & $2334(3)$ & Santa Maria & $2294(26)$ & $1271(25)$ \\
\hline$I A C-11$ & $3330(6)$ & $1811(12)$ & IAC -8 & $2849(16)$ & $2522(1)$ \\
\hline $\mathrm{BR}-11$ & $2545(21)$ & $1261(26)$ & EMCOPA 301 & $2836(17)$ & $1515(18)$ \\
\hline$U F V-3$ & $2485(24)$ & $1115(27)$ & Go 79-1039 & $3011(11)$ & $1305(23)$ \\
\hline Timbira & $2254(28)$ & $1308(21)$ & UFV-2 & $3351(5)$ & $1307(22)$ \\
\hline UFV-4 & $3386(4)$ & $1322(20)$ & UEV-1 & $2809(18)$ & $977(28)$ \\
\hline IAC-9 & $2864(13)$ & $2026(9)$ & $U F V-5$ & $2864(13)$ & 1359 (19) \\
\hline$B R-79-63$ & $2662(19)$ & $1787(14)$ & $\mathrm{BR}-10$ & $2861(15)$ & $2180(5)$ \\
\hline IAC -8 & 2685 & 2205 & IAC-8 & 3159 & 2418 \\
\hline IAC-12 & 3199 & 1728 & $I A C-12$ & 3236 & 1853 \\
\hline Tropical & 2643 & 1636 & Tropical & 2690 & 1606 \\
\hline
\end{tabular}




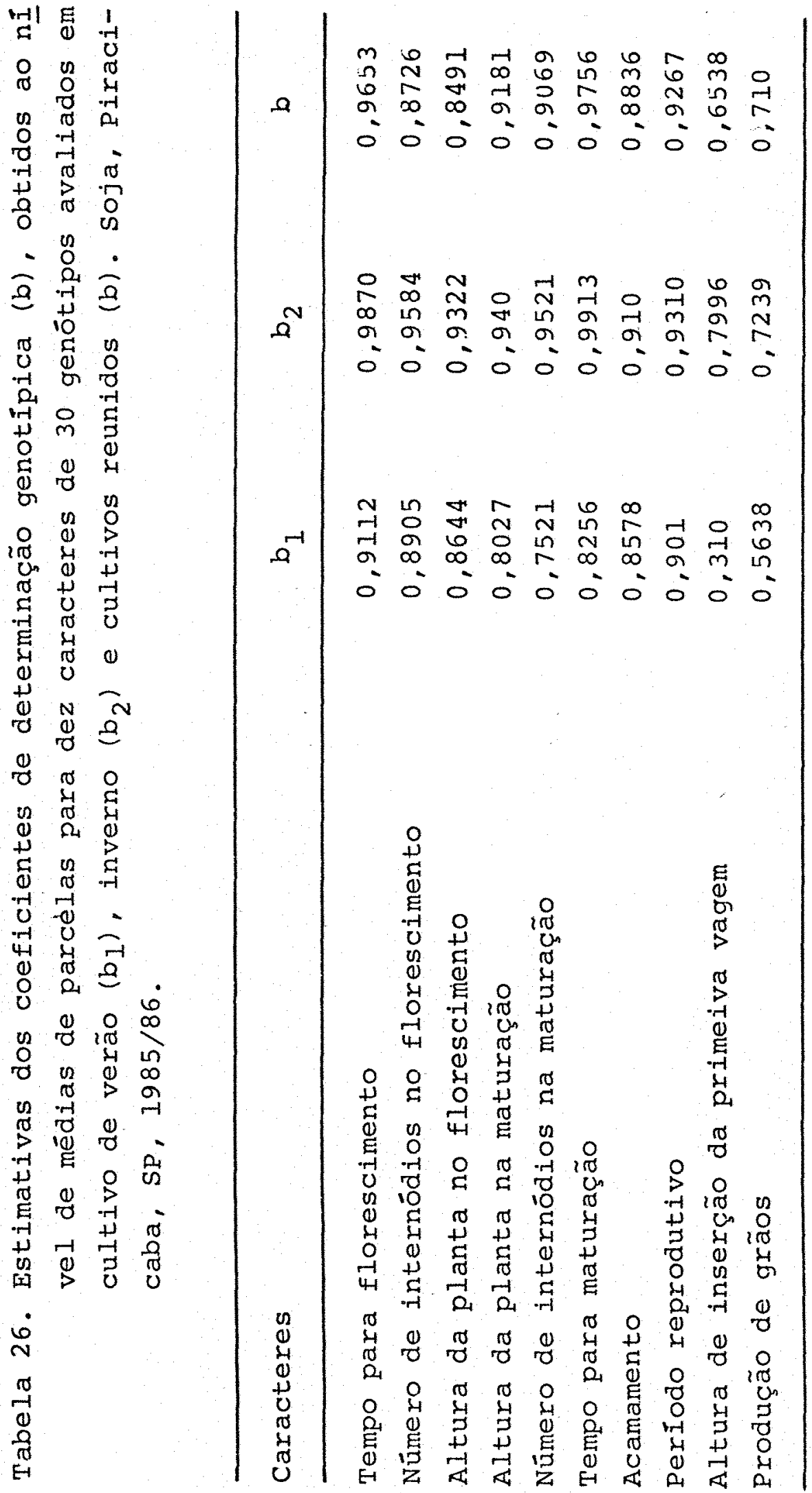


84.

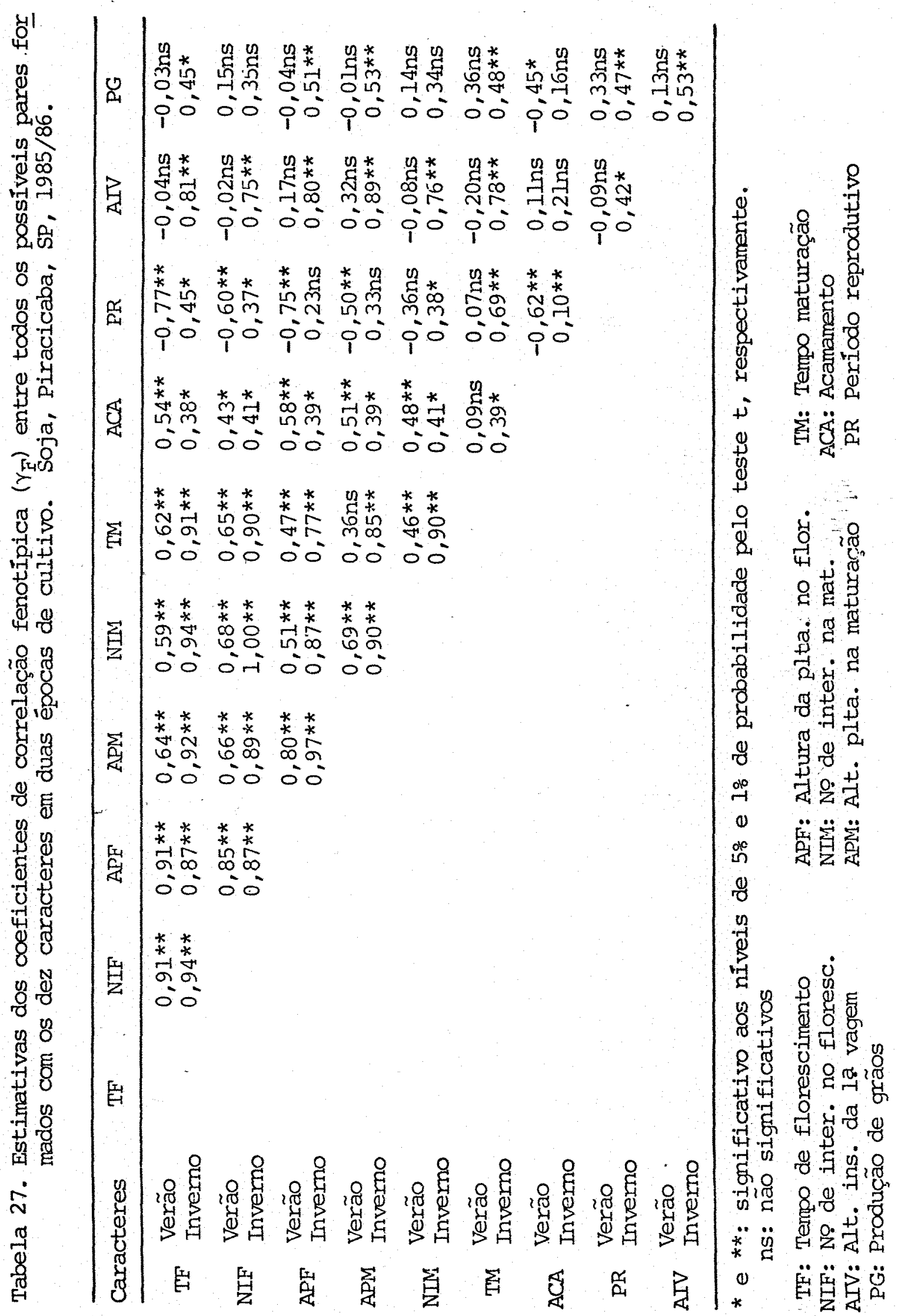


Tabela 28. Estimativas das correlações ( $r$ ) entre épocas para dez caracteres. Soja, cultivos de verão e inverno. Piracicaba, SP, 1985/86.

Caracteres

$r$

Tempo para florescimento

$0,44 *$

Altura da planta no florescimento

$0,55 * *$

Número de internódios no florescimento

$0,48 *$ *

Altura da planta da maturação.

$0,61 * *$

Número de internódios na maturação

$0,56 * *$

Tempo para maturação

$0,43 *$

Acamamento

$0,24 \mathrm{~ns}$

Altura de inserção da primeira vagem

0,42 *

Período reprodutivo

$0,27^{\mathrm{ns}}$

Produção de grãos

$0,3,5 \mathrm{~ns}$

* e **: Significativos aos niveis de $5 \%$ e $1 \frac{0}{\circ}$ de probabilidade pelo teste $t$, respectivamente.

ns: Não significativo 
86.

$\underline{A} \underline{P} \underline{\mathrm{N}} \underline{\mathrm{I}} \underline{\mathrm{C}} \underline{\mathrm{E}}$ 
87.

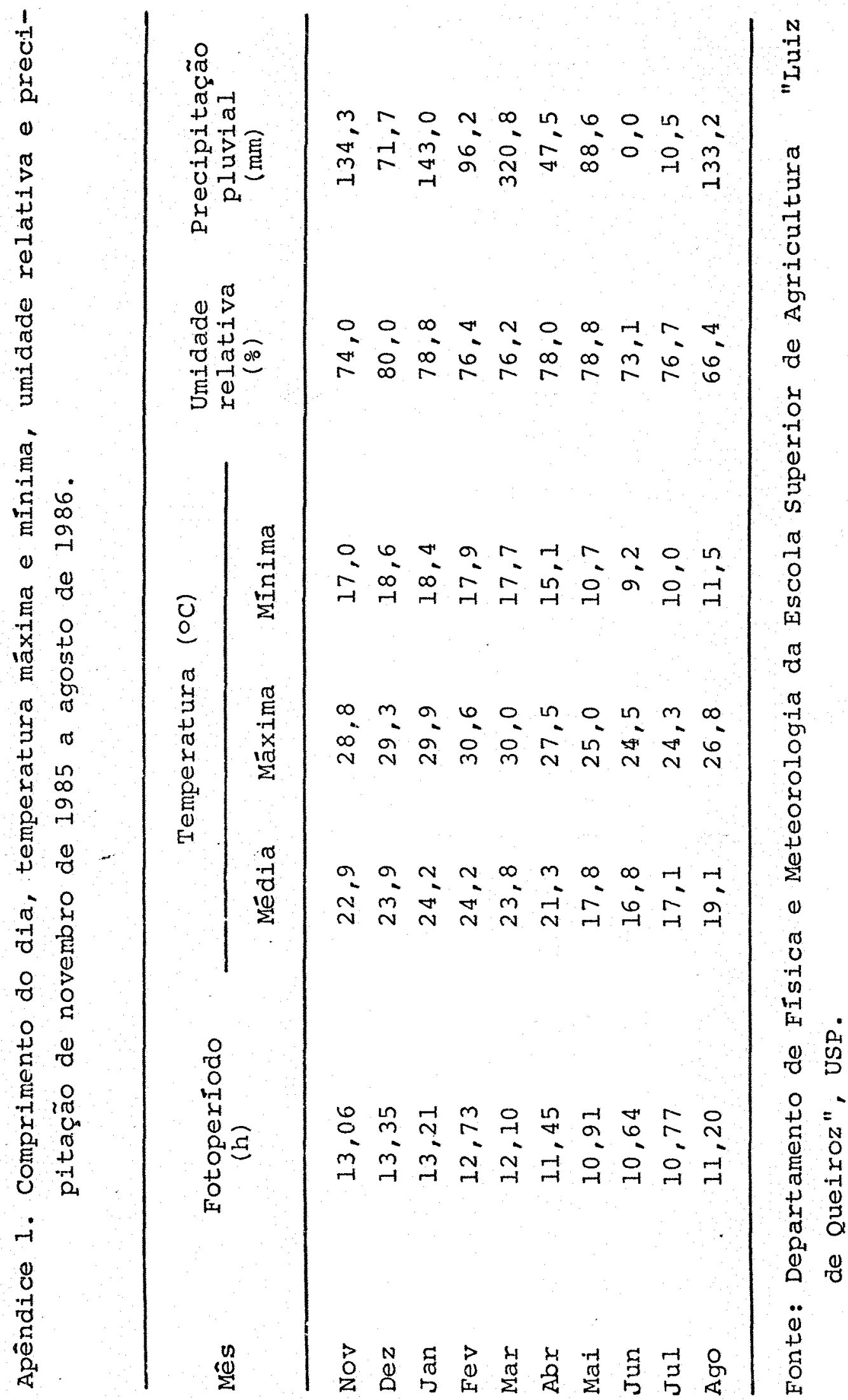

